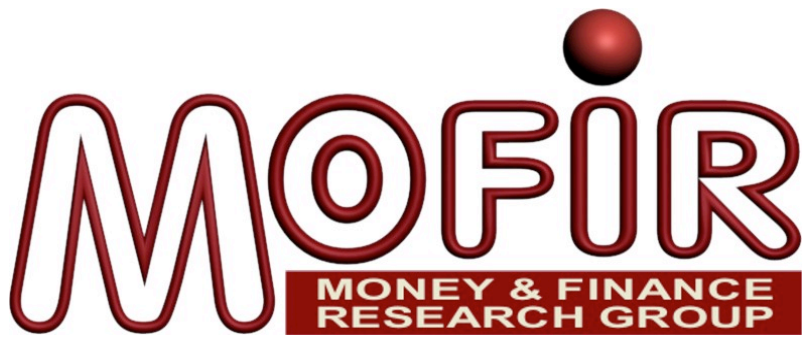

\section{RELATIONSHIP LENDING IN A FINANCIAL TURMOIL}

Giorgio GobBI

Bank of Italy

ENRICO SETTE

Bank of Italy

MoFiR working paper $n^{\circ} 59$

March 2012 


\title{
Relationship lending in a financial turmoil.*
}

\author{
Giorgio Gobbi, Enrico Sette \\ Bank of Italy
}

February 20, 2012

\begin{abstract}
This paper sheds new light on the value of relationship lending by studying whether, after Lehman's default, banks provided a steadier flow of credit and charged lower interest rates, to those firms they established a closer relation with. By exploiting the presence of multiple banking relationships, we are able to control for firms' and banks' unobserved characteristics. Results show that credit growth has been higher if: i) the lending relation was longer; ii) the distance between the bank and the firm shorter; iii) the bank held a larger share of total credit. Similarly, banks increased the cost of credit less to firms they had a longer relation with and they were closer to. We also explore whether the effect of relationship lending depended upon bank or firm characteristics, or on the concentration of the local credit market. Finally, we test whether the effect of relationship lending changed during the crisis with respect to a pre-crisis period.
\end{abstract}

Keywords: relationship lending, credit supply, cost of credit, financial crisis.

\section{Introduction}

The 2007-2008 financial crisis had a very strong impact on financial intermediaries and triggered a deep recession in most advanced economies. Banks needed to absorb a large shock to their funding and capital, which was transmitted to the real sector, through a reduction in the supply of credit to firms. A key question, then, is understanding what factors contributed to dampen the transmission of the shock from banks to firms. In this

${ }^{*}$ The views expressed in this paper are our own and do not necessarily coincide with those of the Bank of Italy. This paper is a substantially revised version of a paper previously circulated with the same title. We thank Jan Bena, Emilia Bonaccorsi di Patti, Andrea Generale, Joao Santos, seminar participants at Bank of Italy, EIEF, ESWC2010, MoFir 2012, Royal Economic Society 2012 for helpful comments. Stefania De Mitri provided excellent research assistance. We are solely responsible for any mistake. Corresponding author: Enrico Sette, enrico.sette@bancaditalia.it 
paper we study whether relationship lending contributed to mitigate the tightening in credit supply after the default of Lehman. To this aim, we provide a causal estimate of the effect of relationship lending on the change in the quantity and price of credit. We measure the strength of the relationship between a bank and a firm through the duration of the relationship, a measure of the geographical distance between the firm and the bank, the banks' share of total credit to the firm. As a first step, we study whether, in the year following the default of Lehman Brothers, banks provided a steadier flow of credit to those firms they established a closer relation with. Then, we analyze whether, in the same period, banks priced credit differently according to the strength of the relation they had with borrowers. We also test whether the effect of relationship lending depends upon firm or bank characteristics, upon the concentration of local credit markets, and if the effect of relationship lending changed after the crisis compared to a pre-crisis period.

The effect of relationship lending on credit supply (in terms of quantities and in terms of prices) is ambiguous both according to the theory and to the available empirical evidence. On the one hand, banks may be willing to support firms by ensuring them a smooth flow of credit, as part of a long-term implicit contract in which banks accumulate private information about the firm, allowing them to make more efficient lending decisions. On the other hand, relationship banks acquire an informational monopoly and may hold firms up, by not granting further credit or by charging higher costs, as firms have little opportunity to switch to new lenders, in particular during a crisis. Our results allow us to answer the important question of which of these effects prevails during a period of financial turmoil.

Our empirical analysis is based on information from a sample of more than 30,000 Italian corporate borrowers - mostly small and medium-sized - and their lending banks. The vast majority of the firms in our sample rely only on intermediate loans as a source of external finance and about 90 per cent of them borrow from more than one bank. Multiple banking is a long standing characteristic of bank-firm relationships in Italy (Foglia et. al, 1998; Detragiache et al., 2000). This feature of the sample plays a key role in our identification strategy, as it allows us to control for firms' and banks' unobserved characteristics, using the methodology introduced by Khwaja and Mian (2005) and (2008). Firm fixed effects control for firm's unobserved heterogeneity (firm level demand for credit, firm's quality, riskiness, etc.) which are key determinants of both the flow and the cost of credit. In addition, since our focus is on relationship-specific variables, we can include bank fixed effects that control for the extent to which banks have been hit by the crisis, their lending policy, and all other bank-specific unobserved heterogeneity. 
We focus on the 12 months following the default of Lehman Brothers, since in Italy this was the time when the crisis exploded in its full force, and its transmission to the real sector effectively began. This entails some important advantages. First, focussing on a period of crisis allows us to investigate the effect of relationship lending on banks' credit decisions during a situation of strong stress. The literature points out that the value of relationship lending becomes manifest precisely in times in which firms and banks are hit by shocks. Second, this enables us to compare the crisis to a pre-crisis period, providing evidence on whether relationship lending had a stronger, or a weaker effect in crisis than in normal times. Third, the crisis originated in the financial sector, outside Italy, and was largely unexpected, at least in its depth. Therefore, firms did not have time to adjust their borrowing as a function of their expectation of how much each bank was going to be hit by the crisis, which is thus an exogenous shock with respect to the structure of the lending relationships existing at the onset of the crisis. This, together with the inclusion of both firm and bank fixed effects allows us to identify a causal effect of tighter lending relationships on credit growth and on banks' pricing of credit.

Finally, Italy is an excellent laboratory for our analysis. In Italy SMEs are highly bank dependent for their funding, so that the firms included in our sample had little opportunity to get funding from other sources than banks. Then, studying the dynamics of bank credit amounts to studying the availability of external finance for most of the firms in our sample. Moreover, although Italian banks have been affected by the financial crisis, systemic stability has not been endangered and government intervention has been very limited (Panetta et. al., 2009). Hence, lending policies of Italian banks were not affected by explicit or implicit constraints imposed by Governments as conditions to receive public support (and anyway they would be captured by bank fixed effects).

Our work contributes to the literature in several ways: we estimate the effect of relationship lending on credit availability and on the cost of credit controlling for firm and bank unobservable characteristics. In this way, we are able to achieve a clean identification of the causal effect of tighter lending relationships on banks' credit supply. We test the causal effect of relationship lending during the Great Recession: a period of crisis in which banks need to deleverage, but the demand for credit by firms is high, and it is precisely in such circumstances that the value of relationship lending, if any, is particularly important. Moreover, we explore whether the effect of relationship lending depends upon firm characteristics such as size, leverage, profitability, and upon bank heterogeneity (capital position, banks' reliance on the interbank market, as well as size and usage of securitizations). We investigate whether the effect of relationship lending 
during the crisis is affected by the concentration of the local credit market. Finally, and in our view, this is an important contribution, we provide first evidence about the differences in the effect of relationship lending in crisis as opposed to non-crisis periods.

Hence, this work contributes to the vast literature on relationship lending. This has been documented to be an important feature of firm financing in bank oriented financial systems such as Japan (Aoki and Patrick, 1994), Germany (Harhoff and Körting,1998) and Italy (Angelini et al.,1998) as well as in more market oriented ones as the U.S. (Petersen and Rajan, 1994; Berger and Udell, 1995). Boot (2000) and Ongena and Smith (2000) review the first wave of research in this area, Berger and Udell (2006) discuss the role of relationship banking on the background of the far reaching transformations experienced by the financial industry in more recent years.

A large empirical literature provides evidence about the benefits and costs of relationship lending (see Degryse et al. 2009 for an exhaustive review). A first strand of the literature focuses on the effect of closer credit relationships on collateral requirements and on the cost of credit. The available evidence indicates that relationship borrowers pledge less collateral (recent contributions include Agarwal and Hauswald 2010 and Bharath et al. 2009). Most studies on US data find that tighter relations are associated with lower rates, while the opposite occurs when investigating European data (Degryse et al. 2009). A second strand of the literature investigates the effect of tighter credit relationships on credit availability. Petersen and Rajan (1994) show that the primary benefit of building close ties with an institutional creditor is that the availability of financing increases; the effects on the price of credit are instead smaller. Elsas (2005) shows that firms that borrow from a small number of banks, or concentrate the bulk of their funding in one relation with an intermediary, and preserve their relation for a relatively long period, face lower financial constraints and experience better credit terms and conditions. Bonaccorsi di Patti and Gobbi (2007) show that it is costly for a firm to interrupt an existing relation and find new sources of finance.

However, recent evidence indicates that firms that switch to new banks obtain more favorable conditions, in terms of loan amounts, in terms of collateral requirements, or in terms of lower rates (Gopalan et al. 2010, and Ioannidou and Ongena 2010). These papers find evidence of the presence of hold-up costs of relationship lending. A further potential cost of relationship lending for firms, is lower diversification of bank finance. This has been identified in Detragiache et al. (2000) as a key determinant of the number of relations firm struck with banks.

From the perspective of banks, establishing a relationship requires that banks can extract ex-post rents from firms to ensure the ex-ante investment in collecting and process- 
ing soft information is profitable (Petersen and Rajan, 1995). However, establishing closer relations with firms may be costly for banks, as it may lead to sub-optimal portfolio diversification and lock-in the investment in case of firm distress. This seems to have been the case in Japan in the 1990s when banks delayed the restructuring of the corporation with which they had close relationships (Caballero et al., 2008).

A few recent works investigate the degree of cushioning provided to firms by tighter relationships with their banks during a downturn. Bodenhorn (2003) using data from a US bank in mid 19th century shows that borrowers with longer relations were more likely to have loan terms renegotiated during the credit crunch of 1857. Jiangli et al. (2009) use survey data from four Asian countries to investigate whether the intensity of banking relationships ensured greater credit availability to firms during the 1998 Asian financial crisis. Their results show that Korean and Thai firms with looser relationships experienced a higher likelihood of being credit constrained, while the opposite occurred for Philippine firms. Neither of these works fully control for firm and bank unobserved heterogeneity, nor provide an assessment of the different effect of relationship lendign before and after a crisis.

Carvalho et al. (2010) show that listed firms experienced a drop in their stock prices if banks they had a close relation with suffered strong equity losses. In a companion paper, Gobbi and Sette (2010) show that firms which concentrated their bank borrowing within few banks, experienced a smaller credit contraction during the crisis.

We also contribute to the literature studying the effect of the financial crisis, and more generally of banks' balance sheet conditions, on credit supply. Santos and Winton (2008) compare the pricing of loans for bank-dependent borrowers with the pricing of loans for borrowers with access to public debt markets. They find that loan spreads rise in recessions, but firms with public debt market access pay lower spreads and their spreads rise significantly less in recessions. Santos (2011) focuses on the impact of banks' exposure to the crisis on loan spreads, and finds that banks more exposed to the crisis increased rates more than those less exposed, and that the effect was stronger for bank-dependent borrowers. Finally, Santos and Winton (2011) show that the relative bargaining power of banks and borrowers plays a crucial role in shaping banks' reactions, in terms of higher spreads on loans, to worsening in borrowers' cash flows. Iyer et al. (2011) show that Portuguese banks that were more exposed to interbank funding contracted credit more. Working on Italian data, Bonaccorsi di Patti and Sette (2010) find a significant effect of banks' reliance of interbank funding, liquidity, and profitability on credit supply during the crisis. Their results also indicate that loan charge-offs, and the reliance on interbank funding have a significant effect on interest rates charged to 
borrowers. Finally, Albertazzi and Marchetti (2010) explore the presence of evergreening by banks on Italian data after Lehman, and find that larger less capitalized banks reallocated loans away from riskier firms.

The paper is structured as follows: section 2 discusses the empirical strategy and the testable hypotheses, section 3 describes the data and descriptive statistics, section 4 shows results, section 5 concludes.

\section{Empirical strategy}

\section{$2.1 \quad$ The model}

As a first step we explore the effect of relationship lending on the growth of credit, and we estimate the following model:

$$
\begin{aligned}
& \Delta \text { credit }_{i, j}=+\beta_{1} \text { duration }_{i, j}+\beta_{2} \text { distance }_{i, j}+\beta_{3} \text { share }_{i, j}+ \\
& \beta_{4}(\text { drawn } / \text { granted })_{i, j}+\beta_{5} \log (\text { credit })_{i, j}+\alpha_{i}+\gamma_{j}+\varepsilon_{i, j}
\end{aligned}
$$

The dependent variable, $\Delta$ credit $_{i, j}$, is the percentage change in revolving credit lines granted to firm $i$ by bank $j$. We focus on revolving credit lines because: i) they are unsecured, so that soft information is especially important for screening and monitoring borrowers; ii) they can be called or renegotiated at short notice by banks, while other forms of credit such as term loans have defined reimbursement plans which cannot be modified in the short run.

We study primarily credit granted and not on credit drawn, although we also show results from a regression for the growth of drawn credit. Credit granted and credit drawn provide complementary information for our purpose. The analysis of credit granted is informative about the decision of banks to grant credit to a firm with which it has tighter relations. The analysis of credit drawn is informative about the extent to which a firm draws more credit from banks with which it holds tighter relations. Banks typically use information on the usage of loans (for example the ratio between credit used and credit granted) to assess the fragility of the borrower. This is particularly true for credit lines: an intensive use of a credit line may trigger a renegotiation of the line. Then, firms may want to use more the lines provided by relationship banks, as the latter may not draw much inference on the firm's situation from its usage of credit lines. Credit granted and credit drawn may differ significantly in the case of revolving credit lines, since, in our 
sample period, Italian banks charged fees and commissions mostly on credit drawn. ${ }^{1}$

We include three variables to capture the strength of the relation between banks and firms. The first is duration $_{i, j}$, the number of years from September 2008 since firm $i$ borrows from bank $j$. The second is distance $_{i, j}$, a dummy variable taking the value one if at September 2008 bank $j$ has a branch in the same post code in which firm $i$ has its headquarter, and it is based on the reasonable assumption that if a firm borrows from a bank, it does so through the bank's branch closest to its headquarter. The third measure for the strength of the relationship between the lender and the borrower is share $_{i, j}$, the share of total revolving credit lines to firm $i$ granted by bank $j$ at September 2008 .

We also control for the share of drawn to granted credit at September $2008\left(\right.$ drawn $\left._{\operatorname{mganted}} \operatorname{gra}_{i, j}\right)$, which measures the extent to which the firm is using the available credit commitment, and for the initial size of the loan (credit lines, or total loans) by bank $j$ to firm $i$ at September 2008, $\log$ (credit), to capture size effects, which may determine the extent to which a credit line grows further.

Importantly, we always include firm fixed effects $\alpha_{i}$ to control for firm-level demand for credit and for other firm's unobservable characteristics such as riskiness, quality, financial fragility, etc. Their omission could lead to biased estimates: banks may be willing to establish longer relations with better firms, which could also be those suffering less from the impact of the crisis, and thus obtain credit more easily.

Finally, we always include a full set of bank fixed effects $\gamma_{j}$. These are important to control for the extent to which different intermediaries have been hit by the financial crisis. It also controls for banks' unobserved characteristics that may influence both the strategies followed by banks in building relations with customers, and the credit policy implemented during the crisis.

As a second step, we study the effect of relationship lending on interest rates. We have data on rates on different types of loans (term loans, revolving credit lines, etc.) which are not easily comparable. Term loans, or loans backed by account receivables are less risky than revolving credit lines, as they are typically collateralized. For this reason, we choose to focus on rates on revolving credit lines, as these are easily comparable across banks, they represent a critical source of finance for firms, and the corresponding spreads (and fees) can be renegotiated by banks at short notice. In this case the equation we estimate is:

\footnotetext{
${ }^{1}$ This is not the case anymore due to new rules on fees and commissions structure set out by the Italian Government.
} 


$$
\begin{aligned}
\Delta \text { int_rate }_{i, j}= & +\lambda_{1} \text { duration }_{i, j}+\lambda_{2} \text { distance }_{i, j}+\lambda_{3} \text { share }_{i, j}+ \\
& \lambda_{4}(\text { drawn } / \text { granted })_{i, j}+\lambda_{5} \log \left(\text { credit }_{i, j}+\alpha_{i}+\gamma_{j}+\varepsilon_{i, j}\right.
\end{aligned}
$$

where $\Delta$ int_rate $e_{i, j}$ is the absolute change in the Annualized Percentage Rate (APR) charged by bank $j$ on the credit lines used by firm $i$ between September 2008 and September 2009. This is computed as the average interest rate paid by firms on outstanding balances at the end of the quarter, including commissions and fees (origination fees, late fees, monthly service charges). Changes in the Euribor, the reference rate for loans on the Italian market, are common to all borrowers and are absorbed by the fixed effects. Then, our results can also be interpreted as an analysis of the effect of relationship lending on the change in the spread on revolving credit lines applied to borrowers. We use the effective APR, which includes both the rate and the fees and commissions charged for the use of the credit facility. However, we also study the APR net of fees and commissions and results are qualitatively unchanged.

The other controls are the same as in equation 1, again computed at September 2008. The change in funding costs experienced by banks between September 2008 and September 2009 is controlled for by bank fixed effects. Then, this model aims at identifying the causal effect of duration, distance, and share of credit on the extent to which changes in banks' funding costs are passed-through into changes in the cost of revolving credit lines for non-financial firms.

In both the equation for credit quantity and in that for interest rates, our measure of distance is based on the physical proximity between the borrower and the lender. An alternative measure of distance explored in the literature refers to functional distance (Alessandrini et al. 2009), that is, the distance between a local branch of the lender, where information is collected and lending relationships are established, and its headquarter, where lending policies and ultimate decisions are typically taken. Then, we also run regressions including a measure of functional distance (a dummy taking the value one if the banks' headquarter is in the same province as the firms' headquarter) and it is never significantly different from zero when we also control for physical distance (results available upon request). Hence, we prefer to focus on our measure of geographical distance.

\subsection{Testable hypotheses}

Our empirical specification allows us to test the following hypotheses: 
H1: closer relationships have a positive effect on credit growth. In particular:

- $\beta_{1}>0$ - firms are granted more credit from the banks they have a longer relationship with. This is based on the idea that longer relations allow the bank to obtain more information about the borrower.

- $\beta_{2}<0$ - firms are granted more credit from banks whose branches are located closer to the firm's headquarter. This is based on the idea that closer borrowers are easier and cheaper to monitor.

- $\beta_{3}>0$ - firms are granted more credit from banks holding a larger share of total credit to the firm. Banks that are more exposed to a firm hold more information about this firm, and thus are more willing to provide credit. Alternatively, a bank is more locked-into the relation as its stake is larger and has to support the firm during a difficult period to reduce the risk the firm does not repay its debt.

This is tested against the alternative hypothesis that closer relationships have a negative effect on credit growth, based on the idea that banks hold up firms they have a closer relation with, as these have fewer opportunities to switch to other banks, especially in times of crisis. Moreover banks may not want to excessively increase their exposure towards the same firm, in particular during a severe recession.

H2: closer relationships reduce the cost of credit. In particular:

- $\lambda_{1}<0$, firms obtain cheaper credit from banks they have a longer relation with. This, again, is consistent with the idea that longer relations allow the bank to obtain more information about the borrower.

- $\lambda_{2}>0$, firms obtain cheaper credit from banks whose branches are located farther away from the firm's headquarter.

- $\lambda_{3}<0$ - firms obtain cheaper credit from banks holding a larger share of total credit to the firm. Again, this may be due to the bank holding more information about the firm, or to the bank being "forced" to price loans less aggressively to firms which they are more exposed to.

This is tested against the alternative hypothesis that banks increase the cost of credit more to firms they have a closer relation with. This is again based on the "hold-up" theory. 
H3: the effect of closer relationships on either credit quantity or cost depends upon firms characteristics. In particular, closer relationships have stronger effect on more opaque or more financially fragile firms. This is based on the idea that the soft information embedded in relationship lending is particularly important if firms are more difficult to screen or monitor (opaque firms), or if firms experience financial difficulties.

H4: the effect of closer relationships on either credit quantity or cost depends upon the extent to which banks have been hit by the turmoil in interbank markets, their capitalization, their size which may proxy for banks' ability to use soft information.

H5: the effect of relationship lending depends upon the concentration of the local credit markets, in particular it is stronger the more concentrated the credit market. This is based on the idea that banks are more willing to maintain a relationship with borrowers if the ability of these to switch to other banks is lower, so that banks have greater ability to extract rents from the relationship.

H6: the effect of relationship lending changed after the crisis (after Lehman's default) with respect to a pre-crisis period.

\section{Data and descriptive statistics}

The data on credit to Italian non-financial corporations are from the Italian Credit Register ("Centrale dei Rischi", CR). This is maintained by the Bank of Italy (the central bank) and collects from all intermediaries operating in Italy individual information on borrowers with outstanding exposure (credit commitments, credit drawn, guarantees) above 75,000 Euros with a single intermediary. The database includes all different forms of bank credit (loans backed by account receivables, term loans, revolving credit lines) together with information about the granting institution and the identity (tax code) of the borrower. From the Credit Register we obtain the total outstanding debt of a firm, and we identify the five intermediaries with the largest shares of credit granted to the firm. ${ }^{2}$ The relationship between a firm and each bank represents our observational unit. We compute all credit received from banks in September 2008 and September 2009, and we compute its growth rate. The financial crisis in Italy exploded after the default

\footnotetext{
${ }^{2}$ This choice is motivated by the need to compute the duration of the relationship. This requires downloading several years of the CR database, month by month. Doing that for all relationships would yield an enormous and intractable database. We chose to focus on the 5 largest relations as this is the median number of relations in our sample. The mean is 5.1.
} 
of Lehman Brothers: disruptions in interbank markets precipitated and credit started decelerating at a fast pace since September 2008 (Figure 1).

For interest rates, we again use data from a special section of the CR (the Taxia database), which contains information on the interest rate and the fees and commissions charged on different forms of loans. This register includes data from a subset of about 130 Italian banks accounting for more than 80 percent of total bank lending in Italy.

Individual intermediaries may be part of a banking group. Typically, both lending and funding policies are decided at the banking group headquarters. Therefore, we aggregate the credit to any firm from all banks belonging to the same banking group. Hence, the controls for relationship lending are computed on the basis of the relationship between a firm and a banking group. In the paper "bank" should therefore be understood as "banking group".

The sample used in the estimation includes relationships of Italian banks with nonfinancial corporations included in the Company Account Data System (CADS) data base. The initial sample counts about 34,000 firms. However, we select firms that are granted revolving credit lines by at least two banks to be able to include firm-fixed effects in the estimation, and this reduces somewhat the sample size.

Moreover, we drop firms that are not using available revolving credit lines at September 2008, because it is hard to think that such credit lines will grow if they are unused. The presence of unsued credit lines is due to the fee structure prevailing in the Italian market in our sample period, according to which firms were charged for their actual usage of credit lines (peaks of use were particularly penalized), and not for the availability of the line. Finally, we exclude firms that have bad loans at September 2008. We include both relations still in place at September 2009, and relations which have been terminated. In such a case granted credit is set to zero at September 2009. ${ }^{3}$

Overall, our sample includes 78,432 credit relationships by about 25,500 firms. The average size of a relationship (granted credit for a revolving credit line) at September 2008 was 566,000 Euros, the median 135,000. At September 2009 these were 444,000 and 100,000, respectively. ${ }^{4}$ For the analysis of interest rates, the sample is smaller, as the dataset includes information by about 130 intermediaries. In this case, the sample includes 50,809 relationships.

Table 1 shows balance sheet statistics of the firms in the sample (these data are from

\footnotetext{
${ }^{3}$ In a robustness check, we also run regressions on the sample of relationships that were in place at both September 2008 and September 2009, thus excluding relationships that have been terminated.

${ }^{4} \mathrm{~A}$ borrower is included in the CR if its total exposure towards an intermediary is above 75,000 Euros. Therefore, there are granted revolving credit lines below that limit as borrowers also get term loans, or loans backed by account receivables from the same bank.
} 
December 2007, the latest balance sheet available before the default of Lehman). The median value of assets is 9.2 Million Euros, Leverage is around 75\%, ROE is $3.6 \%$. These features reflect structural characteristics of Italian firms, which are on average smaller and more leveraged than their European counterparts. Table 2 shows the distribution of firms according to size, riskiness (measured by Altman Z-score), sector, geographical location. More than 50 percent of the sample is made by micro and small firms ${ }^{5}, 45$ per cent are industrial firms, about 38 percent operate in the service sector; more than 60 percent of them are located in the North, the richest area of the country. Finally, about 60 percent of the firms have the six lowest Z-scores (measured on a scale of increasing riskiness from 1 to 9 according to the methodology developed by Altman et al. 1994), while about one third are classified as risky.

Descriptive statistics of banks in the sample are shown in Table 3. All variables come from banks' consolidated balance sheets at June 2008, with the exception of securitizations, which are the cumulative flow of securitizations done by banks in 2004-2006. ${ }^{6}$ The median capital ratio (regulatory capital over risk-weighted assets) is around 11 percent, well above the regulatory minimum of 8 percent. Reliance on interbank funding is on average low (3.9 percent), but its distribution is heterogeneous across banks, with a strong positive correlation with bank size. The average interbank funding to asset ratio is 19 percent for the 10 largest (by total assets) banks. The same applies to the share of securitizations to total assets. The loan charge-off ratio (loan charge offs to total loans) is on average 0.39 percent and this is not very correlated with bank size. Finally, the size distribution of banks is quite skewed, with the five largest groups holding about half of total assets.

Table 4 shows the distribution of the growth rate of revolving credit lines granted, in each relationship. Revolving credit lines have a very large rate of change, since the start of a new line may lead to growth rates above 1,000 percent. Hence, we winsorize the growth rate at the 5th and 95th percentile. However, all results hold if we winsorize at the first top and bottom percentiles and if we use the difference in log credit between September 2009 and September 2008 as a dependent variable (with and without winsorizing the data). While the median growth rate of revolving credit lines is zero, the 25 -th percentile is -65.8 percent, the 40 -th percentile is -20 percent, and credit growth is still negative at the 45 -th percentile of the distribution, indicating that credit decreased in almost half of the relationships. The mean is slightly positive, 0.31 per-

\footnotetext{
${ }^{5}$ This follows the European Union definition, based on both the number of employees and revenues. Small and micro firms have less than 50 employees, and revenues are below 10 million Euros.

${ }^{6}$ We do this since the market for securitizations dried up in 2007.
} 
cent, also reflecting the fact that there are a few large increases in the growth of credit lines. We compute the growth rate of credit, instead of using the difference in the log of credit granted, as the former allows to retain information about relationships that are terminated (in this case, credit growth is -100 percent). We believe this is an important part of the information when studying the effect of relationship lending on credit supply. Moreover, log changes are not a good approxiamtion of growth rates when the latter are big. However, we estimated all parts of the paper using the change in log as a dependent variable and all results hold (some results are even stronger).

Table 4 also shows the distribution of the change in the APR on revolving credit lines, gross of fees and commissions. We winsorize changes in the gross APR at the 5th and 95th percentile, as it displays relatively large changes. ${ }^{7}$ It can be seen that rates decreased on average by about 3.6 percentage points, reflecting the cuts in the policy rates implemented by the ECB between September 2008 and September 2009, and the easing of the tensions in interbank markets. However, the 1 month Euribor, the reference rate for loans to non-financial corporations, dropped much more so that spreads increased in the 12 month following the default of Lehman, as shown in Table 4 and in Figure 2.

The distribution of the control variables is shown in Table 5. About one third of the relations are with a bank that does not have branches in the same postcode as the firms' headquarters. The duration of each relation is on average 5.9 years (the variable is truncated at 7 years). To compute the duration of the relationship between a firm and a bank, we take into account mergers and acquisition among banks, so that if a bank is acquired by another bank we are able to track the original relation and correctly compute its duration. ${ }^{8}$ The average share of credit held by a bank in a relationship is around 24-28 percent depending on whether this is computed over credit granted, or credit drawn.

The correlation among the control variables is not large (Table 6). The most correlated variables are the share of credit held by the bank and the size of the loan from the bank, but their correlation is only around 0.4 .

\footnotetext{
${ }^{7}$ This is due to the fact that rates are obtained by dividing cumulative interest rates paid by products (amount outstanding times days). Then credit lines used for only a few days, for example to pay wages, or taxes, may give rise to a few very large gross APRs, due to fees and commissions, which are reflected in large changes.

${ }^{8}$ Suppose bank B acquires bank A in, say, 2006. If we observe that a firm had a relation with bank A in 2004 and 2005, and then with bank B in 2006, 2007 and 2008, we attribute a duration of 5 years to the relation.
} 


\section{Results}

\subsection{Credit Quantity}

Results from the estimation of equation (1) are shown in Table 7. Column 1 shows estimates of the baseline regression. Distance has a negative and significant coefficient, indicating that banks that are geographically closer to the firm increase credit commitments more (contract them less) than banks that are located farther away. The growth rate of credit from closer banks is about 2.9 percentage points higher than that of credit from more distant banks. The duration of the relationship has a positive and significant coefficient, indicating that banks increase credit commitments more if they have a longer relationship with the firm: credit growth from banks that are one more year into the relationship with the firm is about 0.8 percentage points higher. The share of revolving credit lines to the firm committed by the bank has a positive and significant coefficient: credit growth from banks with a one percent larger share is 0.5 percentage points higher.

These results hold when controlling for the size of the credit line at the beginning of the period and for the ratio between drawn and granted credit, and both controls have the expected sign. A one percent increase in the initial size of the credit lines is associated with a 0.48 percentage points lower credit growth; if drawn to granted credit is one percentage point higher, credit grows by 0.06 percentage points more.

Column 2 shows estimates of the model for the rate of growth of credit winsorized at the 1st and at the 99th percentiles of its distribution, and results are unchanged. Coefficients are larger in size because the rate of growth of revolving credit lines is now much larger, with the 99th percentile of the distribution being around 1,000 percent. However, results are qualitatively unchanged.

Then, we separately investigate the intensive margin and the probability that a relationship in place at September 2008 is terminated by September 2009. Column 3 shows results from the base regression estimated on the sample of relationships that are still alive at September 2009 (the intensive margin). There is little difference with respect to the baseline regression: distance is negative and significant (p-value 0.08), duration and share are positive and highly significant. We also run this regression using the delta $\log$ of credit as a dependent variable and all results, shown in Column 4, hold. Column 5 displays estimates from a linear regression model for the probability that a relationship in place at September 2008 is terminated by September 2009. The dependent variable here is a dummy variable taking the value one if a relationship has positive credit granted at September 2008 and has no credit granted at September 2009. About 15 percent of the relationships have been cut in our sample period. Estimates 
are consistent with previous results: banks that are geographically distant have a 1.1 percent higher probability of terminating a relationship, banks having a one year older relationship with the firm are 0.3 percent less likely to terminate the relationship, and banks holding a one percentage point larger share of total credit are 0.08 percent less likely to terminate the credit relationship.

Finally, in column 6, we shows estimates for a version of equation (1) in which the dependent variable is the growth rate of drawn credit, and results are analogous to those of the baseline model. Here, however the interpretation of results is different as banks often use data about the usage of available credit lines by firms as part of their monitoring process of borrowers. A sudden increase in drawn credit may signal that the firm is experiencing difficulties, or that it was hit by a shock that could undermine its creditworthiness. Then, upon observing changes in drawn credit banks typically collect further information about the borrower. Our results then suggest that firms use more intensely the credit lines granted by banks they have a closer relationship with, likely because relationship banks hold more information about firms, and are likely to put less weight on the information coming from the usage of credit lines.

All regressions control for both firm and bank fixed effects. Hence, coefficients capture the behavior of banks lending to the same firm as a function of characteristics of the relationship, controlling for the impact of the crisis on the bank. This provides an estimate of the causal effect of distance, length of the relationship and share of total credit to the firm held by the bank, on credit growth. Then, these results are consistent with hypothesis H1: tighter bank-firm relationships have a positive, causal, effect on the availability of credit.

\subsection{Cost of Credit}

In this section we study whether banks price credit differently as a function of the strength of the lending relationship they have with firms. To this aim, we estimate equation 2 and results are shown in Table 8. Column 1 displays estimates from the baseline model. Banks that do not have branches in the same post code as the firm headquarter raise interest rates (absolute change of the gross APR on revolving credit lines) by 17 basis points more than banks with branches in the same post code as the firm's headquarter. The duration of the relation is negative and significant. The change in the cost of credit from a bank with which a relation is one year older, is 22 basis points lower. Finally, the share of total credit held by the bank is positive and significant, although the effect is small: banks holding a share of total credit (drawn) 
one percentage point larger, increase the cost of credit by 0.7 basis points less.

Columns 2 and 3 show results from regressions including a dummy variable taking the value one if credit granted (column 2) or credit drawn (column 3) increased in the sample period. These may be controls for relation-specific demand for credit (although they may be somewhat endogenous). Coefficients of distance, duration of the relationship, share of total credit to the firm are unchanged. Column 4 shows a further robustness check, which consists in including the share and the initial level of the credit line computed on credit granted instead of credit drawn, and again results are unchanged.

Column 5 shows results from a regression in which the dependent variable is a dummy taking the value one if the gross APR increased in the sample period. It can be seen that results are qualitatively the same as in the base model. Distance increases the probability the gross APR goes up by about 2 percentage points, one more year into the relationship reduces that probability by 0.8 percentage points; the other controls are not statistically significant.

Finally, column 6 shows the baseline regression estimated on the APR net of fees and commissions, ${ }^{9}$ and results are qualitatively the same as for the gross APR. Distance has a positive effect, duration a negative one. Now the share of total credit becomes negative and significant.

Again, all regressions include firm and bank fixed effects. The latter capture changes in banks' unobserved characteristics between September 2008 and September 2009, including bank-specific changes in the cost of funding and in general in balance sheet conditions, as well as changes in banks' appetite for risk, which are key determinants of banks' pricing policy of credit.

Overall, results are consistent with hypothesis H2: closer relationships have a causal effect on the cost of credit, as banks raise interest rates (and spreads, as the reference rate, the Euribor, is common to all borrowers) less to firms they have a closer relationship with.

\subsection{Firm Heterogeneity}

In this section we explore whether the effect of relationship lending is heterogenous across firms. To do so, we interact regressors of the base model with dummy variables identifying whether a firm is riskier, or more opaque. To measure firms' riskiness we use the Z-score, firms' leverage, firms' ROE. For the Z-score, the dummy for riskier firms takes the value one if firm's Z-score is greater or equal than 7; for leverage, the dummy

\footnotetext{
${ }^{9}$ The average change in net APR is -1.74 , the median is -1.92 ; the standard deviation is 1.95 . The distribution has been winsorized at the 5 th and 95 th percentiles that are -5.1 and 1.9 , respectively.
} 
for high leverage firms takes the value one if firm's leverage is in the top quartile of the distribution; the dummy for less profitable firms takes the value one if firm's ROE is in the bottom quartile of the distribution. To measure firms' opaqueness we use firms' size and firms' share of tangible to total assets. To identify small firms, the dummy takes the value one if firms have less than 49 employees and sales below 10 million Euros; ${ }^{10}$ the dummy for firms with a low share of tangible to total assets takes the value one if firm's ratio of tangible to total assets lies in the bottom quartile of the distribution. All these variables are from December 2007 balance sheets (thus they are predetermined with respect to the crisis).

Results are shown in Table $9^{11}$, and indicate little evidence of heterogeneity in the effect of both distance and duration of the relationship: none of the interaction terms with the dummy capturing firm heterogeneity is statistically significant. The share of total credit to the firm held by the bank has a stronger effect for riskier firms and for smaller firms. This is consistent with the hypothesis that banks holding a larger share of total credit to the firm acquire more information and are thus more willing to provide more credit to the firm in times of trouble. The value of such information is particularly important if firms are smaller or riskier. This is also consistent with a "captured lender" story, in which banks have to support borrowers that are less able to get credit from other sources (this is particularly true for smaller and riskier firms) to avoid reducing the chances that previous credit will be repaid.

We then turn to study whether the effect of relationship lending on the cost of credit is heterogenous across firms. Results are shown in Table 10. Distance has a weaker effect if firms have high leverage, although the interaction term is not significantly different from zero, and the total effect for highly leveraged firms is not statistically different from zero. This suggests that if firms are highly leveraged, distance does not matter much in determining a bank's interest rate policy. On the contrary, duration of the relationship has a stronger effect in mitigating interest rate rises (amplifying interest rate cuts) if firms are riskier (higher Z-score, more leveraged, less profitable). The total effect for high-risk firms is almost double that for safer firms; that for more leveraged and less profitable firms is about 50 percent larger than that for less leveraged or more profitable firms. The effect of the share of total credit has little heterogeneity across firms.

Overall these results indicate that hypothesis $\mathrm{H} 3$ is confirmed for what concerns the price of credit, while there seems to be little heterogeneity across firms in the effect of

\footnotetext{
${ }^{10}$ In other words, small firms include "micro" and "small" firms according to the European Union statistical classification.

${ }^{11}$ The sample size is somewhat smaller since for some firms balance sheet information at December 2007 is incomplete.
} 
relationship lending on the growth of credit granted.

\subsection{Bank Heterogeneity}

As a further extension of our results, we investigate whether the controls for relationship lending have a different effect as a function of banks' exposure to the crisis, and of banks' size which may proxy for banks' ability to use soft information. Again, we interact the measures of relationship lending with dummy variables capturing a set of bank characteristics: bank capitalization, bank reliance on interbank funding, bank reliance on securitization prior to the crisis, bank's loan charge-offs (a measure of prospective capital), and bank assets. ${ }^{12}$

To identify banks with low capital, we use a dummy variable taking the value one if the bank has a capital ratio below 10 per cent (this corresponds to 2 percent excess capital above the regulatory minimum); for reliance on interbank funding, we use a dummy variable taking the value one if bank's share of interbank borrowing to total assets is in the top quartile of the distribution; for reliance on securitization, we use a dummy variable taking the value one if the ratio of cumulative securitizations in 20042006 to total assets is in the top quartile of the distribution; for loan charge-offs we use a dummy taking the value one if the ratio of bank's loan charge-offs in June 2008 income statement to loans is above the median; finally, for bank size, we use a dummy variable taking the value one if a bank is in the 10 largest banking groups measured by consolidated assets. We prefer to use dummy variables for bank characteristics instead of continuous variables since the effect of balance sheet variables may be non-linear, and it may be difficult to identify any effect in a model also including a full set of bank fixed effects. However, this is not innocuous, since changing the definition of, say, low capital banks, or of banks highly reliant on interbank funding, may affect thousands of observations, as a bank, especially if it is large, has many credit relationships.

Results for credit quantity are shown in Table $11 .{ }^{13}$ Distance has a negative effect for banks with a high ratio of loan charge-offs to total loans and for larger banks. Moreover, while the interaction terms between distance and the dummy variables for bank reliance on interbank funding and securitizations are not significant, the total effect of distance is

\footnotetext{
${ }^{12}$ Descriptive statistics for these variables, which have been descreibed in Section 3, are shown in Table 3 .

${ }^{13}$ The sample size is smaller than for the full sample because we do not have consolidated balance sheet information for Italian branches of foreign banks. Hence, we do not know whether these banks truly have low capital, high reliance on interbank funding, etc. In this case, the balance sheet conditions of their parent company are very relevant for their lending policy, and we prefer to exclude them from the sample. This also applies to the sample size of regressions for the cost of credit.
} 
statistically significant, and negative, only for banks highly reliant on interbank funding and on securitization prior to the crisis. The effect of duration is similar across banks, except that it is stronger and significantly different from zero for banks highly reliant on interbank funding. Finally, the positive effect of the share of total credit if weaker for banks with high charge-offs to total loans. This suggests that such banks were less willing to increase their exposure towards borrowers if they already had a relatively large share of total credit towards those borrowers. This result is in contrast with the "captured-lender" story.

Table 12 displays estimates for the regressions on changes in the cost of credit. In this case, there is some evidence of heterogeneous effects of the duration of the relationship. That is larger in absolute value (i.e. more negative) if banks were more reliant on securitization before the crisis, if banks have a larger share of loan charge-offs, and if banks are larger. Reliance on securization may capture both the extent to which banks had access to a cheaper source of funding which dried up during the crisis, and the extent to which banks relied on the originate-to-distribute business model prior to the crisis. These results indicate that such banks cut the cost of credit more aggressively to relationship borrowers during the crisis, possibly placing more attention to relationship lending as the originate-to-distribute model became unfeasible. A similar argument may explain the results for larger banks. Loan charge-offs are a measure of prospective capital, as they include future losses that can be reasonably expected given current information. Then, banks with more loan charge-offs are likely those that will have to restore capital the most in the future. The latter result is consistent with Santos (2011) who, using data from US corporations, finds larger increases in loan spreads if the lending bank has higher loan charge-offs.

Overall these results are consistent with hypothesis H4: the effect of relationship lending on both credit quantity and price is influenced by bank size and by measures of banks' exposure to the financial crisis (reliance on interbank funding, on securitizations, ratio of charge-offs to total loans).

\subsection{Concentration of the local credit market}

In this section we explore whether the effect of relationship lending depends upon the concentration of the local credit market the firm operates in. The theory suggests that banks are more willing to support relationship borrowers, especially in hard times, if these are less likely to switch to other lenders (so that relationship lenders will be more able to extract rents in the future): in other words, the value of keeping a relationship 
is higher if local credit markets are less competitive (more concentrated). Petersen and Rajan (1995) show that younger firms have easier access to bank credit in more concentrated credit markets. Zarutskie (2006) finds that newly formed firms use less bank debt if the local credit market becomes more competitive. This evidence suggests that tighter competition reduces the value of building relationships with new firms, those that are most affected by information asymmetries. Here, we tackle a closely related but different question, as we study whether the effect of relationship lending during a crisis depends upon the degree of competition of the local credit market. To this aim, we interact the measures of relationship lending with the Herfindahl index of the Local Labor Market Area the firm is based in. ${ }^{14}$ Results are shown in Table $13 .{ }^{15}$ Columns 1 and 2 display estimates for regressions on the growth of credit quantity. ${ }^{16}$ They differ in that column 2 includes interactions with all controls, while column 1 includes only interactions between the Herfindahl index and the controls for relationship lending. Only the interaction with the duration of the relationship is significant, and positive: the duration of the relationship has a positive and significant (at the 10 percent level) effect on the growth of credit if the Herfindahl index is greater than 0.111. The Herfindahl index has a median of 0.26 and only 18 LLMAs have an Herfindahl index below 0.111. In the distribution of the Herfindahl index weighed by relationships, the median is 0.14 and 0.111 is close to the 25 th percentile. The effect is significant at the 5 percent level if the Herfindahl index is greater than 0.129.

This result is consistent with the idea that the value of maintaining a long-lasting relationship is higher, the more concentrated is the credit market, so that banks find it more profitable to invest in relationship capital if firms are less likely to switch to other banks in the future, which in turn is less likely if the local credit market is more concentrated. Columns 3 and 4 show results for the cost of credit. Interestingly, none of the interactions with the Herfindahl index is significant. However, the effect of distance on interest rates is significant, and positive, if the Herfindahl index is large enough (above 0.14 , about the median value of the distribution weighed by relationships). This again indicates that the effect of relationship lending is stronger if credit markets are relatively concentrated.

Overall, this evidence supports hypothesis H5. The positive effect of the length of the

\footnotetext{
${ }^{14}$ LLMAs are defined by the Italian National Statistics Institute (Istat) as a set of adjacent municipalities linked by daily commuter flows for work purposes. According to the 2001 Census, Italy counts 686 LLMA. Bank of Italy estimates, available upon request, indicate that 80 per cent of bank-firm relationships are located within the same LLMA.

${ }^{15}$ We also run regressions using dummy variables for the Herfindahl index above the median or above the 25 th or the 75 th percentile and results are qualitatively unchanged.

${ }^{16}$ The level of the Herfindahl index is absorbed by the firm fixed effects.
} 
relationship on credit growth is stronger the more concentrated is the local credit market, and it is not significantly different from zero if the local credit market has very low concentration (Herfindahl index below 0.111). Similarly, the cost of credit is increased more the more distant the borrowers only if the local credit market is concentrated enough.

\subsection{Comparing the crisis to a pre-crisis period}

An important question is what have been the effect of relationship lending in the precrisis period, and in particular, whether this has changed between the pre-crisis and the crisis period. To address this question, we add to our dataset credit relationships of non-financial corporations between December 2005 and December 2006, a year in which Italy experienced a moderate economic expansion (GDP growth was 2.2 percent, the highest of the decade in Italy) and financial markets did not suffer any special tension. Overall credit to non-financial firms grew at a fast pace in 2006 (12 per cent on average over the previous year).

To test whether the role of relationship lending on the supply of credit and on the cost of credit, changed during the crisis, we estimate the following model:

$$
\begin{aligned}
& \Delta \text { credit }_{i, j}=+\beta_{1} \text { duration }_{i, j}+\beta_{2} \text { distance }_{i, j}+\beta_{3} \text { share }_{i, j}+ \\
& \beta_{4}(\text { drawn } / \text { granted })_{i, j}+\beta_{5} \log (\text { credit })_{i, j}+\alpha_{i}+\gamma_{j}+ \\
& D\left(\text { crisis }^{2}=1\right) *\left[\delta_{1} \text { duration }_{i, j}+\delta_{2} \text { distance }_{i, j}+\delta_{3} \text { share }_{i, j}+\right. \\
& \left.\delta_{4}(\text { drawn } / \text { granted })_{i, j}+\delta_{5} \log (\text { credit })_{i, j}+\alpha_{i}+\gamma_{j}\right]+\varepsilon_{i, j}
\end{aligned}
$$

where, importantly, we add firm*period and bank*period fixed effects, so as to control for firm specific and bank specific unobserved heterogeneity both in the crisis and in the pre-crisis period. The model for the regression on the $\triangle \mathrm{APR}$ is analogous. The dummy $D$ (crisis $=1)$ takes value one if data refer to the September 2008-September 2009 (crisis) period; it takes value zero if data refer to the December 2005-December 2006 (pre-crisis) period.

Results for credit quantity are shown in Table 14. Distance is negative and in the pre-crisis period, the estimated coefficient is -1.95 , while in the post-crisis period, it is -2.89. While we cannot reject the hypothesis that the effect of distance is the same in both periods, it is statistically different from zero only during the crisis. As regards duration, the effect is positive and statistically significant both in the pre- and in the 
post-crisis period, although in the latter the effect is weaker, and significantly so. The share of total credit to the firm held by the bank is positive and significant in both periods, and the effect is not statistically different across periods. This result is more in line with an interpretation of share as a measure of the strength of the credit relationship, than with an interpretation of share as a measure of "capture" of the lender: in a period of good economic conjuncture, banks are less averse to write loans off and firms, even troubled ones, are more able to start new credit relationships. Hence, in the captured lender story, the effect of the share of toal credit should be stronger in the crisis than in the pre-crisis period. However, this is not consistent with the evidence.

Estimates for the regression on $\triangle \mathrm{APR}$ are shown in column 2 of Table 14. Distance is not significant in the pre-crisis period, but it becomes positive and significant in the post-crisis period. On the contrary, the length of the relationship has the same effect in both periods and it is negative and significant.

Overall, this evidence suggests that distance matters both for quantity and for interest rates only during the crisis. This is consistent with the idea that the importance of monitoring borrowers increased during the crisis, and banks privileged borrowers located closer to the bank's branch, possibly because the cost of monitoring is lower. On the contrary, the duration of relationships has a weaker effect during the crisis than in the pre-crisis period on credit quantity, while it has the same effect in the pre- as in the post-crisis period for what concerns the cost of credit.

These results are partly consistent with hypothesis H6. Only the effect of distance changed somewhat after Lehman default, while that of the duration of the relationship and of the share of credit held by the bank remained broadly unchanged.

\section{Conclusion}

This paper investigates whether, in the year after the default of Lehman, banks provided a steadier flow of credit to those firms they established a closer relation with. Results indicate that the longer the relation and the shorter the distance between the bank and the firm, the higher credit growth. The same occurs if banks hold a larger share of credit to the firm. The cost of credit increased by a lower amount to spatially close firms and to firms having a longer relation with banks.

The effect of relationship lending on the growth of credit commitments does not change as a function of firms' riskiness or opacity. However, the effect of the length of the relationship on the cost of credit is stronger if firms are riskier, more leveraged, less profitable. 
The effect of relationship lending on the growth of granted credit and on the cost of credit depends upon bank characteristics. Distance has a stronger effect on credit granted if banks hold a larger share of loan charge-offs and if they are bigger, in which case duration has a weaker effect. By contrast, duration has a stronger effect in mitigating an increase in the cost of credit if banks are more reliant on securitizations, hold a larger share of charge-offs to total loans, and if they are larger.

The effect of duration on credit growth also depends upon the concentration of the local credit market: the more concentrated the local credit market, the stronger the effect of duration.

We also study whether the effect of relationship lending changed during the crisis, compared to a pre-crisis period, and find that during the crisis distance had a stronger effect on the cost of credit, while duration had a weaker effect on the growth of credit commitments than in the pre-crisis period.

All regressions control for firm and bank fixed effects, so that results hold conditional on firm unobservable quality, riskiness, demand for credit, and for the impact of the crisis on banks, as well as for other banks' unobservable characteristics.

\section{References}

[1] Agarwal, S., Hauswald, R. (2010), "Distance and Private Information in Lending", Review of Financial Studies 23, 2757-2788.

[2] Albertazzi, U. and Marchetti D. (2010), "Credit supply, flight to quality and evergreening: an analysis of bank-firm relationships after Lehman", Bank of Italy Working Paper n. 756.

[3] Alessandrini, P., Presbitero, A., Zazzaro, A. (2009), "Banks, Distances and Firms' Financing Constraints", Review of Finance 13, 261-307.

[4] Angelini, P., Di Salvo R., Ferri G. (1998), "Availability and cost of credit for small business: Customer relationships and credit cooperatives", Journal of Banking and Finance, 22, pages 925-954.

[5] Aoki, M., Patrick, H. eds. (1994), The Japanese Main Bank System: Its Relevance for Developing and Transforming Economies. Oxford: Oxford Univ. Press.

[6] Beck, T., Demirgüç-Kunt, A., Maksimovic, V. (2008), "Financing patterns around the world: Are small firms different?", Journal of Financial Economics, 89, pages $467-487$. 
[7] Berger, A., Udell, G. (1995), "Relationship Lending and Lines of Credit in Small Firm Finance," Journal of Business, 68, pages 351-379.

[8] Berger, A., Udell, G. (2002), "Small Business Credit Availability and Relationship Lending: The Importance of Bank Organisational Structure", The Economic Journal, 112, pages F32-F53

[9] Berger, A., Udell, G., (2006) "A More Complete Conceptual Framework for SME Finance", Journal of Banking and Finance, 30, pages 2945-2966.

[10] Berger, A., Miller, N.H., Petersen, M., Rajan, R., Stein, J. (2005), "Does Function Follow Organizational Form? Evidence from the Lending Practices of Large and Small Banks", Journal of Financial Economics, 76, pages 237-269.

[11] Bharath, S., Dahiya, S., Saunders, A. , Srinivasan, A. (2009), "Lending Relationships and Loan Contract Terms", Review of Financial Studies, forthcoming.

[12] Bodenhorn, H. (2003), "Short-Term Loans and Long-Term Relationships: Relationship Lending in Early America", Journal of Money, Credit and Banking, 35, pages 485-505

[13] Bonaccorsi di Patti, E., Gobbi G. (2007), "Winners or Losers? The Effects of Banking Consolidation on Corporate Borrowers", Journal of Finance, 62, pages 669-695

[14] Bonaccorsi di Patti, E., Sette, E. (2010), "Bank balance sheets and the transmission of financial shocks to borrowers: Evidence from the 2007-2008 Crisis", Bank of Italy, mimeo.

[15] Boot, A. (2000), "Relationship banking: What do we know?", Journal of Financial Intermediation, 9, pages 7-25.

[16] Caballero, R., Hoshi, T., Kashyap, A. (2008), "Zombie Lending and Depressed Restructuring in Japan," American Economic Review, 98, pages 1943-77.

[17] Degryse, H., Kim, M., Ongena, S. (2009), "Microeconometrics of Banking", Oxford University Press.

[18] Detragiache, E., Garella, P., Guiso, L. (2000), "Multiple versus Single Banking Relationships: Theory and Evidence." Journal of Finance, 55, pages 1133-1161. 
[19] Elsas, R. (2005) "Empirical Determinants of Relationship Lending", Journal of Financial Intermediation, 14, pages 32-57.

[20] Foglia, A., Laviola, S. Marullo Reedtz, P. (1998), "Multiple Banking Relationships and the Fragility of Corporate Borrowers." Journal of Banking and Finance 22, pages 1441-1456.

[21] Gobbi, G., Sette, E. (2010), "Do Firms Benefit from Concentrating their Borrowing? Evidence from the Great Recession", Bank of Italy, mimeo.

[22] Gopalan, R., Udell, G., Yerramilli, V. (2010), "Why do firms form new banking relationships?", Journal of Financial and Quantitative Analysis, forthcoming.

[23] Harhoff, D, Körting T. (1998), "Lending relationships in Germany - Empirical evidence from survey data", Journal of Banking and Finance, 22, pages 1317-1353.

[24] Ioannidou, V. and Ongena, S. (2010). "Time for a Change': Loan Conditions and Bank Behavior when Firms Switch Banks", Journal of Finance, forthcoming.

[25] Jiangli, W., Unal, H., Yom, C. (2009), "Relationship Lending, Accounting Disclosure, and Credit Availability during Crisis", Journal of Money, Credit, and Banking, forthcoming.

[26] Khwaja, A, Mian, A. (2005), "Do Lenders Favor Politically Connected Firms? Rent Provision in an Emerging Financial Market". Quarterly Journal of Economics, 120, 1371-1411.

[27] Khwaja, A, Mian, A. (2008), "Tracing the Impact of Bank Liquidity Shocks: Evidence from an Emerging Market". American Economic Review, 98, 1413-42.

[28] Ongena, S., Smith, D. (2000), "Bank relationships: a Review," in Harker Patrick T., Stavros A. Zenios (eds.), Performance of Financial Institutions: Efficiency, Innovation, Regulation, pages 221-258.

[29] Panetta, F., Angelini P. (coordinators), Albertazzi, U., Columba, F., Cornacchia, W., Di Cesare, A., Pilati, A., Salleo, C., Santini, G., (2009), "Financial sector pro-cyclicality: lessons from the crisis", Bank of Italy Occasional Papers Series, n. 44.

[30] Petersen, M., Rajan, R. (1994), "The Benefits of Lending Relationships: Evidence From Small Business Data", Journal of Finance, 49, pages 3-37. 
[31] Petersen, M., Rajan, R. (1995), "The effect of credit market competition lending relationships", The Quarterly Journal of Economics, CX, pages 407-443.

[32] Santos, J. (2011), "Bank loan pricing following the subprime crisis", Review of Financial Studies, Forthcoming

[33] Santos, J. and Winton, A. (2008), "Bank loans, bonds, and information monopolies across the business cycle", Journal of Finance 63, 1315-1359.

[34] Santos, J. and Winton, A. (2011), "Bank Capital, Borrower Power, and Loan Rates", mimeo.

[35] Zarutskie, R. (2006), "Evidence on the Effects of Bank Competition on Firm Borrowing and Investment", Journal of Financial Economics 81, 503-537. 


\section{Tables and Figures}

Figure 1: Growth rate of loans to non financial firms

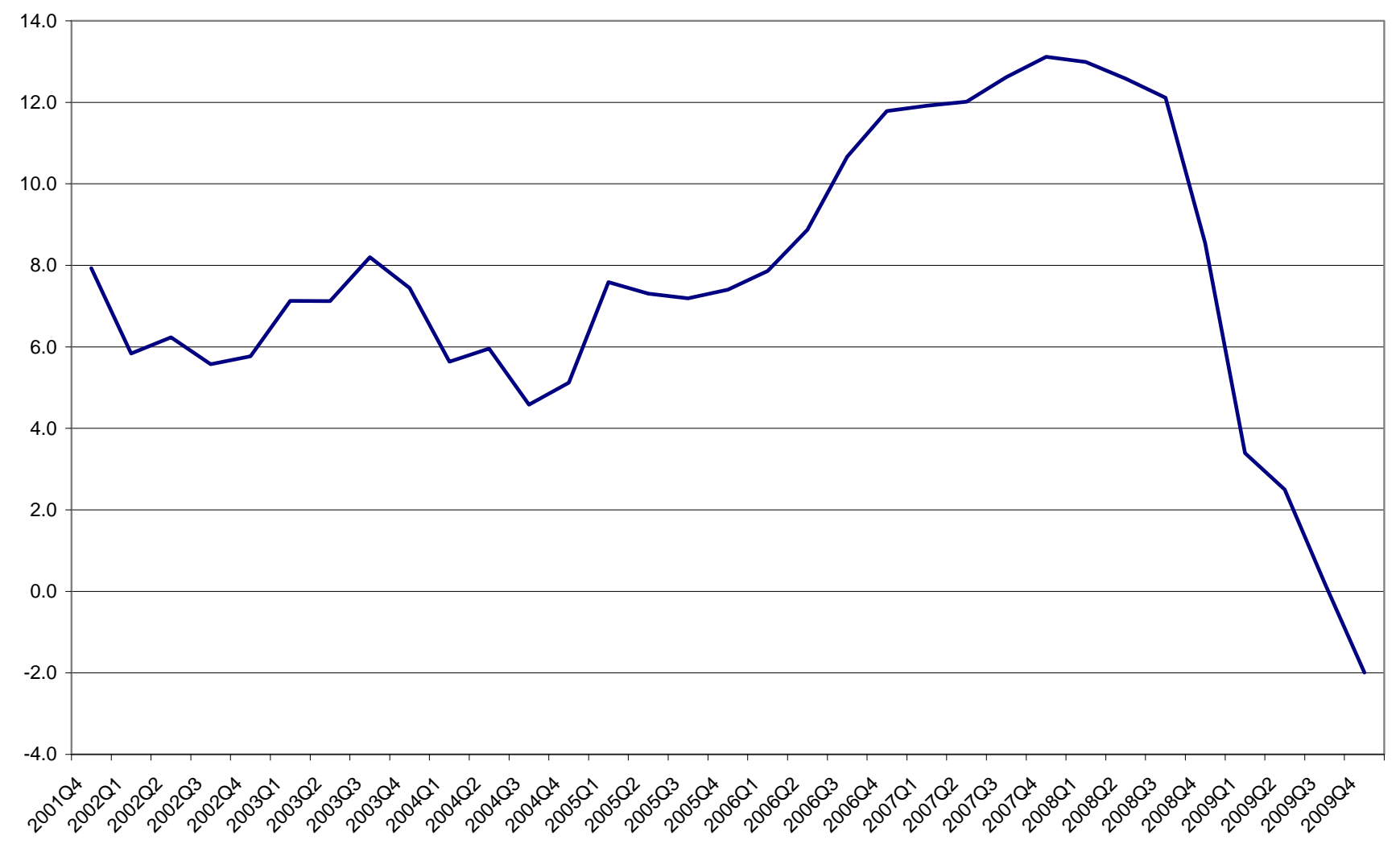


Figure 2: Gross Annual Percentage Rate and Gross APR - 1 Month Euribor Spreads on revolving credit lines to non-financial firms.

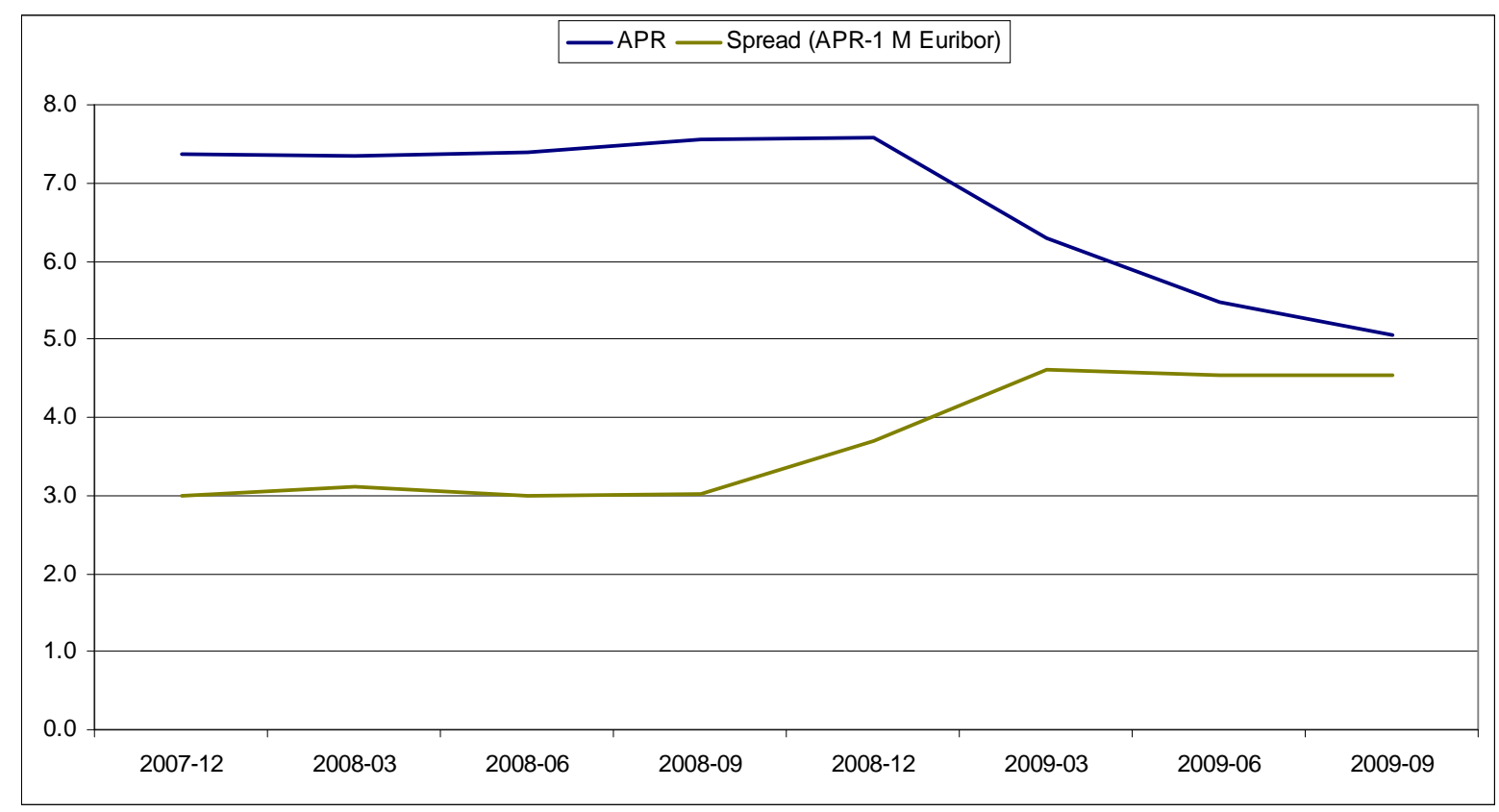

Table 1: Descriptive Statistics of firms

The table shows descriptive statistics of 25493 Italian non-financial firms that obtain credit from at least two banks at September 2008. Data are from firm's Balance sheets included in the Company Accounts data System (Centrale dei Bilanci) and refer to December 2007 balance sheets.

\begin{tabular}{lcccc}
\hline \hline Firms in the sample & Mean & Median & p25 & p75 \\
\hline & & & & \\
Total assets (Mln Euros) & 35.9 & 9.2 & 5.1 & 18.4 \\
ROE & 5.9 & 3.6 & 0 & 12.6 \\
Leverage & 70.5 & 74.6 & 58.3 & 85.9 \\
\hline \hline
\end{tabular}


Table 2: Descriptive Statistics: characteristics of firms

The table shows the distribution of the 25493 Italian non-financial firms included in our sample. Each cell shows percentage of occurrences. Size classes follow the European Union definition and are defined as follows: micro firms are those with less than 10 employees and sales below 2 million Euros, small firms have between 10 and 49 employees and sales between 2 and 10 million Euros, medium firms have between 50 and 249 employees and sales between 10 and 50 million Euros, large firms have more than 250 employees or sales above 50 million Euros. Sector is a macro-aggregate from the NACE classification system. Location refer to the geographical area the firm has its headquarter in. Rating refer to the three macro-classes of the Z-Score. Sound includes firms with Z-score between 1 and 3, Vulnerable includes firms with Z-score between 4 and 6, Risky includes firms with Z-score between 7 and 9 .

\begin{tabular}{|c|c|c|c|}
\hline \multicolumn{2}{|c|}{ SIZE } & \multicolumn{2}{|l|}{ SECTOR } \\
\hline Micro & 4.8 & Industry & 45.4 \\
\hline Small & 48.6 & Services & 38.1 \\
\hline Medium & 38.0 & Construction & 9.1 \\
\hline Large & 8.5 & Other & 7.4 \\
\hline \multicolumn{2}{|c|}{ LOCATION } & \multicolumn{2}{|l|}{ RATING } \\
\hline North & 63.7 & Sound $(1 \leq \mathrm{Z}$-score $\leq 3)$ & 26.3 \\
\hline Center & 20.1 & Vulnerable $(4 \leq$ Z-score $\leq 6)$ & 40.3 \\
\hline South & 16.2 & Risky $(7 \leq$ Z-score $\leq 9)$ & 33.3 \\
\hline
\end{tabular}


Table 3: Descriptive Statistics: characteristics of banks

The table shows descriptive statistics of the banks included in the sample. Capital ratio is the ratio of regulatory capital to risk weighted assets. Interbank funding/Assets is the ratio of interbank funding to total assets. Securitizations/Assets is the ratio of the cumulative assets securitized by the bank between 2004 and 2006 and bank total assets. Loan Charge-offs Ratio is the ratio of loan charge-offs (net loan loss provisions) to total loans. Log Assets is the natural logarithm of assets. All variables are measured at June 2008 and come from consolidated balance sheets submitted to the Bank of Italy (the banking supervisor) by Italian banks and Italian banking groups with the Supervisory Reports.

\begin{tabular}{llll}
\hline \hline & Mean & Median & Std.Dev. \\
\hline Capital ratio & 18.0 & 14.6 & 11.2 \\
Interbank funding/Assets & 3.9 & 1.4 & 9.9 \\
Securitizations/Assets & 1.81 & 0 & 12.8 \\
Loan Charge-offs Ratio & 0.39 & 0.16 & 3.96 \\
Log Assets & 5.95 & 5.78 & 1.60 \\
\hline \hline
\end{tabular}


Table 4: Descriptive Statistics: distribution of interest rate changes The table shows descriptive statistics of the main dependent variables. $\Delta$ Granted Credit (\%) is the percentagte rate of growth of revolving credit lines (overdraft facilities) granted to firm $i$ by bank $j$ between September 2008 and September 2009. The sample refers to credit from Italian banks to 25493 Italian non-financial firms. $\Delta$ Gross APR is the absolute change in the gross (inclusive of fees and commissions) Annual Percentage Rate charged on revolving credit lines granted to 17686 Italian non/financial firms by Italian banks included in the Taxia section of the Italian Credit Register. $\Delta$ Spread on Gross APR is the difference between $\Delta$ Gross APR and the $\Delta 1$ month Euribor rate, the reference rate for revolving credit lines granted to non-financial firms in Italy. Data are from the Italian Credit Register, the 1 month Euribor is from Thomson One - Datastream.

\begin{tabular}{lcllcl}
\hline \hline & Mean & Median & p25 & p75 & Std. Dev. \\
\hline$\Delta$ Granted Credit (\%) & 0.31 & 0 & -65.78 & 0 & 95.63 \\
$\Delta$ Gross APR & -3.61 & -2.78 & -4.92 & -0.30 & 6.32 \\
$\Delta$ Spread on Gross APR & 0.5 & 1.23 & -0.9 & 3.71 & 6.32 \\
& & & & & \\
\hline \hline
\end{tabular}

Table 5: Descriptive statistics: regressors

The table shows descriptive statistics of the regressors used in the empirical analysis. All data are from the Italian Credit Register and refer to 78432 credit relationships between 25493 Italian non-financial firms and Italian banks. Distance is a dummy variable taking the value 0 if, at September 2008, bank $j$ lending to firm $i$ has a branch in the same postcode in which firm $i$ has its headquarter; it takes the value 1 if bank $j$ does not have branches in the same postcode in which which firm $i$ has its headquarter. Duration is the number of years, from September 2008, since firm $i$ borrows from bank $j$ (taking into account M\&As). Share_credit lines_granted is the share of total credit granted, at September 2008, to firm $i$ lent by bank $j$.Share_credit lines_drawn is the share of total credit, at September 2008, drawn by firm $i$ lent by bank $j$. Drawn/Granted is the ratio of drawn to granted credit, at September 2008, relative the credit relationship between firm $i$ and bank $j$. Log_credit_lines_granted and Log_credit_lines_drawn are the log of the initial amount of credit granted and drawn, respectively, at September 2008.

\begin{tabular}{lcllll}
\hline \hline & Mean & Median & p25 & p75 & Std. Dev. \\
\hline Distance (dummy) & 0.33 & 0 & 0 & 1 & 0.47 \\
Duration & 5.9 & 7 & 5 & 7 & 1.75 \\
Share_credit lines_granted & 24.4 & 18.5 & 10.2 & 32.9 & 19.8 \\
Share_credit lines_drawn & 28.5 & 20.3 & 8.5 & 41.4 & 25.9 \\
Drawn/Granted & 68.9 & 70.8 & 25.4 & 99 & 58.8 \\
Log credit_lines_granted & 11.9 & 11.8 & 10.8 & 12.7 & 1.44 \\
Log credit_lines_drawn & 10.9 & 11.1 & 9.8 & 12.2 & 2.17 \\
\hline \hline
\end{tabular}


Table 6: Descriptive statistics: correlation matrix of regressors

The table shows correlations among regressors. These are defined in Table 5. All variables are measured at September 2008 and come from the Italian Credit Register.

\begin{tabular}{lccccc}
\hline \hline & Distance & Duration & Share (granted) & Drawn/Granted & Log(credit) \\
\hline Distance & 1 & & & & \\
Duration & -0.1616 & 1 & & & \\
Share (granted) & -0.0572 & 0.0771 & 1 & 1 & \\
Drawn/Granted & 0.0251 & -0.0285 & -0.0305 & -0.2120 & 1 \\
Log credit_granted & -0.0539 & 0.1092 & 0.4113 & & \\
\hline \hline
\end{tabular}


Table 7: Credit quantity: main regressions

The table shows OLS estimates of regressions for the rate of growth of revolving credit lines granted by the banking system to Italian non-financial firms between September 2008 and September 2009 on measures of the strength of bank-firm relationships. The sample includes 78432 bank-firm relationships from the Italian Credit Register. Control variables are defined in Table 5. All regressions include firm and bank fixed effects. Column 1 shows results for the base regression; Column 2 shows results from a regression on the rate of growth of revolving credit lines winsorized at the 1st and 99th percentiles; Column 3 shows results from bank-firm relationships in place both at September 2008 and at September 2009 (intensive margin); Column 4 shows results from a regression on the delta log credit (this again estimates the effect on the intensive margin); Column 5 shows results for a regression on a dummy variable taking the value 1 if the bank-firm relationship was terminated at September 2009; Column 6 shows results for a regression on the rate of growth of drawn credit. Robust standard errors in parentheses. ${ }^{* * *} \mathrm{p}<0.01,{ }^{* *} \mathrm{p}<0.05$, $* \mathrm{p}<0.1$.

\begin{tabular}{|c|c|c|c|c|c|c|}
\hline & $(1)$ & $(2)$ & $(3)$ & $(4)$ & $(5)$ & $(6)$ \\
\hline VARIABLES & base & winsorize 1-99 & intensive margin & $\Delta \log$ credit & $\operatorname{prob}(\mathrm{cut})$ & drawn \\
\hline distance & $\begin{array}{c}-2.895^{* * *} \\
(1.109)\end{array}$ & $\begin{array}{c}-5.215^{* *} \\
(2.164)\end{array}$ & $\begin{array}{c}-2.105^{*} \\
(1.208)\end{array}$ & $\begin{array}{c}-0.032^{* * *} \\
(0.013)\end{array}$ & $\begin{array}{c}1.108^{* * *} \\
(0.376)\end{array}$ & $\begin{array}{c}-10.50^{* *} \\
(4.406)\end{array}$ \\
\hline duration & $\begin{array}{c}0.792^{* * *} \\
(0.268)\end{array}$ & $\begin{array}{c}2.145^{* * * *} \\
(0.510)\end{array}$ & $\begin{array}{c}0.759^{* * *} \\
(0.292)\end{array}$ & $\begin{array}{c}0.0216^{* * *} \\
(0.003)\end{array}$ & $\begin{array}{c}-0.297^{* * *} \\
(0.0926)\end{array}$ & $\begin{array}{c}5.874^{* * *} \\
(1.053)\end{array}$ \\
\hline share & $\begin{array}{c}0.526^{* * *} \\
(0.0699)\end{array}$ & $\begin{array}{c}2.813^{* * *} \\
(0.164)\end{array}$ & $\begin{array}{c}0.702^{* * *} \\
(0.0849)\end{array}$ & $\begin{array}{c}0.013^{* * *} \\
(0.001)\end{array}$ & $\begin{array}{c}-0.0818^{* * *} \\
(0.0153)\end{array}$ & $\begin{array}{c}2.585^{* * *} \\
(0.146)\end{array}$ \\
\hline drawn/granted & $\begin{array}{c}0.0680^{* * *} \\
(0.00967)\end{array}$ & $\begin{array}{c}0.158^{* * *} \\
(0.0213)\end{array}$ & $\begin{array}{c}0.0746 * * * \\
(0.0111)\end{array}$ & $\begin{array}{c}0.0008^{* * *} \\
(0.0001)\end{array}$ & $\begin{array}{c}-0.0135^{* * *} \\
(0.00313)\end{array}$ & $\begin{array}{c}-0.508^{* * *} \\
(0.0397)\end{array}$ \\
\hline $\log (\text { credit })_{t-1}$ & $\begin{array}{c}-48.10^{* * *} \\
(1.684)\end{array}$ & $\begin{array}{c}-126.7^{* * *} \\
(4.063)\end{array}$ & $\begin{array}{c}-64.00^{* * *} \\
(1.988)\end{array}$ & $\begin{array}{c}-0.879 * * * \\
(0.019)\end{array}$ & $\begin{array}{c}-0.781^{* *} \\
(0.314)\end{array}$ & $\begin{array}{c}-141.08^{* * *} \\
(3.146)\end{array}$ \\
\hline Observations & 78432 & 78432 & 65946 & 65946 & 78432 & 78432 \\
\hline
\end{tabular}

Robust standard errors in parentheses - All regressions include firm and bank fixed effects. 
Table 8: Interest rates - Base regression

The table shows OLS estimates of regressions for the change in the Annual Percentage Rate, including fees and commissions, on revolving credit lines granted by the banking system to Italian non-financial firms between September 2008 and September 2009 on measures of the strength of bank-firm relationships. The sample includes a cross section of 50809 bank-firm relationships included in the Taxia database (information on interest rates from the Italian Credit Register). Control variables are defined in Table 5. All regressions include firm and bank fixed effects. Column 1 shows results for the base regression; Column 2 includes a dummy variable taking the value 1 if credit granted increased between September 2008 and September 2009; Column 3 includes a dummy variable taking the value 1 if credit drawn increased between September 2008 and September 2009; Column 4 includes the share and the log of credit granted instead of credit drawn as a control; Column 5 shows results for a regression on a dummy variable taking the value 1 if the growth APR increased in the sample period; Column 6 shows results for a regression on the Annual Percentage Rate net of fees and commissions. Robust standard errors in parentheses. ${ }^{* * *} \mathrm{p}<0.01,{ }^{* *} \mathrm{p}<0.05,{ }^{*} \mathrm{p}<0.1$.

\begin{tabular}{|c|c|c|c|c|c|c|}
\hline & $(1)$ & $(2)$ & $(3)$ & (4) & $(5)$ & $(6)$ \\
\hline distance & $\begin{array}{c}0.169^{*} \\
(0.0880)\end{array}$ & $\begin{array}{c}0.168^{*} \\
(0.0880)\end{array}$ & $\begin{array}{c}0.167^{*} \\
(0.0880)\end{array}$ & $\begin{array}{l}0.181^{* *} \\
(0.0882)\end{array}$ & $\begin{array}{c}2.354^{* * *} \\
(0.616)\end{array}$ & $\begin{array}{c}0.101^{* * *} \\
(0.0270)\end{array}$ \\
\hline duration & $\begin{array}{c}-0.223^{* * *} \\
(0.0207)\end{array}$ & $\begin{array}{c}-0.224^{* * *} \\
(0.0207)\end{array}$ & $\begin{array}{c}-0.223^{* * *} \\
(0.0207)\end{array}$ & $\begin{array}{c}-0.236 * * * \\
(0.0210)\end{array}$ & $\begin{array}{c}-1.093^{* * *} \\
(0.152)\end{array}$ & $\begin{array}{c}-0.0299^{* * *} \\
(0.00654)\end{array}$ \\
\hline share & $\begin{array}{c}0.00770^{* * *} \\
(0.00246)\end{array}$ & $\begin{array}{c}0.00727^{* * *} \\
(0.00246)\end{array}$ & $\begin{array}{c}0.00741^{* * *} \\
(0.00246)\end{array}$ & & $\begin{array}{l}-0.0220 \\
(0.0149)\end{array}$ & $\begin{array}{c}-0.00185^{* * *} \\
(0.000663)\end{array}$ \\
\hline drawn/granted & $\begin{array}{c}-0.00522^{* * *} \\
(0.000876)\end{array}$ & $\begin{array}{c}-0.00483^{* * *} \\
(0.000887)\end{array}$ & $\begin{array}{c}-0.00547^{* * *} \\
(0.000880)\end{array}$ & $\begin{array}{c}0.00458^{* * *} \\
(0.000778)\end{array}$ & $\begin{array}{c}-0.00967^{*} \\
(0.00561)\end{array}$ & $\begin{array}{c}-0.000477^{*} \\
(0.000250)\end{array}$ \\
\hline $\log (\text { credit })_{t-1}$ & $\begin{array}{c}0.398^{* * *} \\
(0.0453)\end{array}$ & $\begin{array}{c}0.388^{* * *} \\
(0.0455)\end{array}$ & $\begin{array}{c}0.386^{* * *} \\
(0.0455)\end{array}$ & & $\begin{array}{l}0.0269 \\
(0.254)\end{array}$ & $\begin{array}{c}0.0158 \\
(0.0115)\end{array}$ \\
\hline $\operatorname{dummy}(\Delta$ granted credit $>0)$ & & $\begin{array}{c}-0.231^{* * *} \\
(0.0731)\end{array}$ & & & & \\
\hline dummy $(\Delta$ drawn credit $>0)$ & & & $\begin{array}{c}-0.234^{* * *} \\
(0.0678)\end{array}$ & & & \\
\hline share (granted credit) & & & & $\begin{array}{c}0.00504 \\
(0.00399)\end{array}$ & & \\
\hline $\log (\text { granted credit })_{t-1}$ & & & & $\begin{array}{c}0.580^{* * *} \\
(0.0890)\end{array}$ & & \\
\hline Observations & 50809 & 50809 & 50809 & 50809 & 50809 & 50809 \\
\hline
\end{tabular}

Robust standard errors in parentheses - All regressions include firm and bank fixed effects. 
Table 9: Firm Heterogeneity - Credit quantity

The table shows OLS estimates of regressions for the rate of growth of revolving credit lines granted by the banking system to Italian non-financial firms between September 2008 and September 2009 on measures of the strength of bank-firm relationships. The sample includes a cross section of 64105-67321 bank-firm relationships involving firms for which complete balance sheet information was available at December 2008. Control variables are defined in Table 5. All regressions include firm and bank fixed effects. Column 1 includes interactions of each regressor with a dummy variable taking the value 1 if the firm's Z score is between 7 and 9; Column 2 includes interactions of each regressor with a dummy variable taking the value 1 if firm's leverage is in the top quartile of the distribution; Column 3 includes interactions of each regressor with a dummy variable taking the value 1 if firm's ROE is in the bottom quartile of the distribution; Column 4 includes interactions of each regressor with a dummy variable taking the value 1 if firm's assets are in the bottom quartile of the distribution; Column 5 includes interactions of each regressor with a dummy variable taking the value 1 if firm's tangible assets are in the bottom quartile of the distribution. Robust standard errors in parentheses. ${ }^{* * *} \mathrm{p}<0.01,{ }^{* *} \mathrm{p}<0.05$, $* \mathrm{p}<0.1$.

\begin{tabular}{|c|c|c|c|c|c|}
\hline \multicolumn{6}{|c|}{ Dependent variable : $\Delta$ credit $(\%)$} \\
\hline & $(1)$ & $(2)$ & $(3)$ & (4) & $(5)$ \\
\hline VARIABLES & High risk & High lever. & Low ROE & Small & Low Tangible \\
\hline distance & $\begin{array}{c}-2.747^{*} \\
(1.454)\end{array}$ & $\begin{array}{l}-1.898 \\
(1.531)\end{array}$ & $\begin{array}{c}-2.792^{* *} \\
(1.406)\end{array}$ & $\begin{array}{c}-2.834^{*} \\
(1.712)\end{array}$ & $\begin{array}{c}-2.459 * \\
(1.295)\end{array}$ \\
\hline duration & $\begin{array}{c}0.745^{* *} \\
(0.356)\end{array}$ & $\begin{array}{l}0.665^{*} \\
(0.382)\end{array}$ & $\begin{array}{c}0.624^{*} \\
(0.347)\end{array}$ & $\begin{array}{c}0.674 \\
(0.479)\end{array}$ & $\begin{array}{c}0.446 \\
(0.330)\end{array}$ \\
\hline share & $\begin{array}{c}0.336^{* * *} \\
(0.0970)\end{array}$ & $\begin{array}{c}0.343^{* * *} \\
(0.0949)\end{array}$ & $\begin{array}{c}0.377^{* * *} \\
(0.0933)\end{array}$ & $\begin{array}{c}0.305^{* * *} \\
(0.112)\end{array}$ & $\begin{array}{c}0.467^{* * *} \\
(0.0909)\end{array}$ \\
\hline drawn/granted & $\begin{array}{c}0.0803^{* * *} \\
(0.0138)\end{array}$ & $\begin{array}{c}0.0844^{* * *} \\
(0.0145)\end{array}$ & $\begin{array}{c}0.0640^{* * *} \\
(0.0128)\end{array}$ & $\begin{array}{c}0.0569 * * * \\
(0.0153)\end{array}$ & $\begin{array}{c}0.0690^{* * *} \\
(0.0120)\end{array}$ \\
\hline $\log (\text { credit })_{t-1}$ & $\begin{array}{c}-48.73^{* * *} \\
(2.267)\end{array}$ & $\begin{array}{c}-47.96^{* * *} \\
(2.206)\end{array}$ & $\begin{array}{c}-47.47^{* * *} \\
(2.166)\end{array}$ & $\begin{array}{c}-43.14^{* * *} \\
(2.422)\end{array}$ & $\begin{array}{c}-46.98^{* * *} \\
(2.146)\end{array}$ \\
\hline distance*dummy & $\begin{array}{l}-0.268 \\
(0.590)\end{array}$ & $\begin{array}{c}-0.0843 \\
(0.589)\end{array}$ & $\begin{array}{c}0.209 \\
(0.609)\end{array}$ & $\begin{array}{l}0.0210 \\
(0.581)\end{array}$ & $\begin{array}{c}1.015 \\
(0.667)\end{array}$ \\
\hline duration*dummy & $\begin{array}{l}-1.123 \\
(2.314)\end{array}$ & $\begin{array}{l}-3.682 \\
(2.328)\end{array}$ & $\begin{array}{l}-0.904 \\
(2.374)\end{array}$ & $\begin{array}{l}-0.487 \\
(2.236)\end{array}$ & $\begin{array}{l}-3.214 \\
(2.792)\end{array}$ \\
\hline share*dummy & $\begin{array}{c}0.312^{*} \\
(0.161)\end{array}$ & $\begin{array}{c}0.274 \\
(0.170)\end{array}$ & $\begin{array}{c}0.257 \\
(0.167)\end{array}$ & $\begin{array}{c}0.431^{* * *} \\
(0.153)\end{array}$ & $\begin{array}{c}0.00493 \\
(0.171)\end{array}$ \\
\hline drawn/granted*dummy & $\begin{array}{c}-0.0256 \\
(0.0212)\end{array}$ & $\begin{array}{c}-0.0355^{*} \\
(0.0215)\end{array}$ & $\begin{array}{l}0.00640 \\
(0.0222)\end{array}$ & $\begin{array}{c}0.0181 \\
(0.0209)\end{array}$ & $\begin{array}{c}-0.0137 \\
(0.0244)\end{array}$ \\
\hline $\log (\text { credit })_{t-1} *$ dummy & $\begin{array}{c}4.619 \\
(3.793)\end{array}$ & $\begin{array}{c}2.460 \\
(3.962)\end{array}$ & $\begin{array}{c}1.197 \\
(3.980)\end{array}$ & $\begin{array}{c}-11.53^{* * *} \\
(3.593)\end{array}$ & $\begin{array}{l}-1.494 \\
(3.972)\end{array}$ \\
\hline Observations & 67213 & 64105 & 67312 & 67321 & 67321 \\
\hline
\end{tabular}

Robust standard errors in parentheses - All regressions include firm and bank fixed effects. 
Table 10: Firm Heterogeneity - Interest rate

The table shows OLS estimates of regressions for the change in the Annual Percentage Rate, including fees and commissions, on revolving credit lines granted by the banking system to Italian non-financial firms between September 2008 and September 2009 on measures of the strength of bank-firm relationships. The sample includes a cross section of 50809 bank-firm relationships included in the Taxia database (information on interest rates from the Italian Credit Register). Control variables are defined in Table 5. All regressions include firm and bank fixed effects. Column 1 includes interactions of each regressor with a dummy variable taking the value 1 if the firm's Z-score is between 7 and 9; Column 2 includes interactions of each regressor with a dummy variable taking the value 1 if firm's leverage is in the top quartile of the distribution; Column 3 includes interactions of each regressor with a dummy variable taking the value 1 if firm's ROE is in the bottom quartile of the distribution; Column 4 includes interactions of each regressor with a dummy variable taking the value 1 if firm's assets are in the bottom quartile of the distribution; Column 5 includes interactions of each regressor with a dummy variable taking the value 1 if firm's tangible assets are in the bottom quartile of the distribution. Robust standard errors in parentheses. $* * * \mathrm{p}<0.01, * * \mathrm{p}<0.05, * \mathrm{p}<0.1$.

\begin{tabular}{|c|c|c|c|c|c|}
\hline \multicolumn{6}{|c|}{ Dependent variable: $\Delta$ Gross APR } \\
\hline & $(1)$ & $(2)$ & $(3)$ & (4) & $(5)$ \\
\hline VARIABLES & High risk & High lever. & Low ROE & Small & Low Tangible \\
\hline distance & $\begin{array}{l}0.207^{*} \\
(0.113)\end{array}$ & $\begin{array}{c}0.265^{* *} \\
(0.120)\end{array}$ & $\begin{array}{c}0.170 \\
(0.112)\end{array}$ & $\begin{array}{c}0.192 \\
(0.131)\end{array}$ & $\begin{array}{l}0.182^{*} \\
(0.101)\end{array}$ \\
\hline duration & $\begin{array}{c}-0.161^{* * *} \\
(0.0273)\end{array}$ & $\begin{array}{c}-0.196^{* * *} \\
(0.0293)\end{array}$ & $\begin{array}{c}-0.198^{* * *} \\
(0.0268)\end{array}$ & $\begin{array}{c}-0.239^{* * *} \\
(0.0350)\end{array}$ & $\begin{array}{c}-0.224^{* * *} \\
(0.0250)\end{array}$ \\
\hline share & $\begin{array}{c}0.00444 \\
(0.00312)\end{array}$ & $\begin{array}{l}0.00620^{*} \\
(0.00331)\end{array}$ & $\begin{array}{l}0.00520^{*} \\
(0.00312)\end{array}$ & $\begin{array}{c}0.00526 \\
(0.00381)\end{array}$ & $\begin{array}{l}0.00562^{*} \\
(0.00293)\end{array}$ \\
\hline drawn/granted & $\begin{array}{c}-0.00367^{* * *} \\
(0.00123)\end{array}$ & $\begin{array}{c}-0.00311^{* *} \\
(0.00129)\end{array}$ & $\begin{array}{c}-0.00561^{* * *} \\
(0.00112)\end{array}$ & $\begin{array}{c}-0.00381^{* * *} \\
(0.00131)\end{array}$ & $\begin{array}{c}-0.00479^{* * *} \\
(0.00106)\end{array}$ \\
\hline $\log (\text { credit })_{t-1}$ & $\begin{array}{c}0.352^{* * *} \\
(0.0556)\end{array}$ & $\begin{array}{c}0.340^{* * *} \\
(0.0587)\end{array}$ & $\begin{array}{c}0.441^{* * *} \\
(0.0559)\end{array}$ & $\begin{array}{c}0.377^{* * *} \\
(0.0630)\end{array}$ & $\begin{array}{c}0.394^{* * *} \\
(0.0529)\end{array}$ \\
\hline distance*dummy & $\begin{array}{l}-0.124 \\
(0.184)\end{array}$ & $\begin{array}{l}-0.322^{*} \\
(0.184)\end{array}$ & $\begin{array}{l}-0.0174 \\
(0.185)\end{array}$ & $\begin{array}{l}-0.0552 \\
(0.177)\end{array}$ & $\begin{array}{l}-0.0832 \\
(0.223)\end{array}$ \\
\hline duration*dummy & $\begin{array}{c}-0.206^{* * *} \\
(0.0458)\end{array}$ & $\begin{array}{c}-0.0976^{* *} \\
(0.0456)\end{array}$ & $\begin{array}{c}-0.123^{* * *} \\
(0.0459)\end{array}$ & $\begin{array}{c}0.0107 \\
(0.0442)\end{array}$ & $\begin{array}{l}-0.0369 \\
(0.0531)\end{array}$ \\
\hline share*dummy & $\begin{array}{c}0.00556 \\
(0.00575)\end{array}$ & $\begin{array}{c}0.00282 \\
(0.00563)\end{array}$ & $\begin{array}{c}0.00431 \\
(0.00568)\end{array}$ & $\begin{array}{c}0.00126 \\
(0.00525)\end{array}$ & $\begin{array}{c}0.00352 \\
(0.00649)\end{array}$ \\
\hline drawn/granted*dummy & $\begin{array}{l}-0.00229 \\
(0.00189)\end{array}$ & $\begin{array}{c}-0.00424^{* *} \\
(0.00191)\end{array}$ & $\begin{array}{l}0.00344^{*} \\
(0.00201)\end{array}$ & $\begin{array}{l}-0.00182 \\
(0.00186)\end{array}$ & $\begin{array}{l}0.000754 \\
(0.00222)\end{array}$ \\
\hline $\log (\text { credit })_{t-1} *$ dummy & $\begin{array}{c}0.142 \\
(0.107)\end{array}$ & $\begin{array}{c}0.137 \\
(0.104)\end{array}$ & $\begin{array}{l}-0.165 \\
(0.105)\end{array}$ & $\begin{array}{c}0.0604 \\
(0.0960)\end{array}$ & $\begin{array}{c}0.00605 \\
(0.119)\end{array}$ \\
\hline Observations & 44023 & 42137 & 44081 & 44084 & 44084 \\
\hline
\end{tabular}

Robust standard errors in parentheses - All regressions include firm and bank fixed effects. 
Table 11: Bank Heterogeneity - Credit quantity

The table shows OLS estimates of regressions for the rate of growth of revolving credit lines granted by the banking system to Italian non-financial firms between September 2008 and September 2009 on measures of the strength of bank-firm relationships. The sample includes a cross section of 76837 bankfirm relationships involving banks for which complete balance sheet information was available at June 2008 (this excludes Italian branches of foreign banks). Control variables are defined in Table 5. All regressions include firm and bank fixed effects. Column 1 includes interactions of each regressor with a dummy variable taking the value 1 if the bank's regulatory capital ratio is below 10\%; Column 2 includes interactions of each regressor with a dummy variable taking the value 1 if bank's interbank funding over total assets is in the top quartile of the distribution; Column 3 includes interactions of each regressor with a dummy variable taking the value 1 if the ratio of bank's flow of securitizations between 2004 and 2006 to total assets is in the top quartile of the distribution; Column 4 includes interactions of each regressor with a dummy variable taking the value 1 if bank's loan charge-offs over total loans are in the top quartile of the distribution; Column 5 includes interactions of each regressor with a dummy variable taking the value 1 if a bank is among the top 10 italian banks for total assets. Robust standard errors in parentheses. $* * * \mathrm{p}<0.01, * * \mathrm{p}<0.05,{ }^{*} \mathrm{p}<0.1$.

\begin{tabular}{|c|c|c|c|c|c|}
\hline \multicolumn{6}{|c|}{ Dependent variable : $\Delta$ credit $(\%)$} \\
\hline & $(1)$ & $(2)$ & $(3)$ & $(4)$ & $(5)$ \\
\hline VARIABLES & Low capital & High Interbank & High Securitiz. & Hi Ch-offs & Top10 \\
\hline distance & $\begin{array}{c}-3.157^{* *} \\
(1.404)\end{array}$ & $\begin{array}{l}-2.136 \\
(2.387)\end{array}$ & $\begin{array}{l}-2.568 \\
(1.711)\end{array}$ & $\begin{array}{c}4.411 \\
(3.332)\end{array}$ & $\begin{array}{c}-0.0754 \\
(1.570)\end{array}$ \\
\hline duration & $\begin{array}{c}0.687^{*} \\
(0.359)\end{array}$ & $\begin{array}{l}-0.202 \\
(0.596)\end{array}$ & $\begin{array}{c}0.797^{*} \\
(0.431)\end{array}$ & $\begin{array}{c}1.031 \\
(0.836)\end{array}$ & $\begin{array}{c}0.806^{* *} \\
(0.364)\end{array}$ \\
\hline share & $\begin{array}{c}0.528^{* * *} \\
(0.0764)\end{array}$ & $\begin{array}{c}0.497^{* * *} \\
(0.101)\end{array}$ & $\begin{array}{c}0.488^{* * * *} \\
(0.0814)\end{array}$ & $\begin{array}{c}0.764^{* * *} \\
(0.106)\end{array}$ & $\begin{array}{c}0.560^{* * *} \\
(0.0809)\end{array}$ \\
\hline drawn/granted & $\begin{array}{c}0.0707^{* * *} \\
(0.0128)\end{array}$ & $\begin{array}{c}0.0257 \\
(0.0248)\end{array}$ & $\begin{array}{c}0.0729^{* * *} \\
(0.0173)\end{array}$ & $\begin{array}{c}0.0865^{* *} \\
(0.0371)\end{array}$ & $\begin{array}{c}0.0412^{* *} \\
(0.0160)\end{array}$ \\
\hline $\log (\text { credit })_{t-1}$ & $\begin{array}{c}-47.88^{* * *} \\
(1.726)\end{array}$ & $\begin{array}{c}-46.34^{* * *} \\
(2.276)\end{array}$ & $\begin{array}{c}-48.75^{* * *} \\
(1.765)\end{array}$ & $\begin{array}{c}-48.96^{* * *} \\
(2.090)\end{array}$ & $\begin{array}{c}-47.79^{* * *} \\
(1.817)\end{array}$ \\
\hline distance*dummy & $\begin{array}{c}0.578 \\
(1.712)\end{array}$ & $\begin{array}{l}-0.903 \\
(2.536)\end{array}$ & $\begin{array}{l}-0.499 \\
(1.955)\end{array}$ & $\begin{array}{c}-7.876^{* *} \\
(3.443)\end{array}$ & $\begin{array}{c}-4.596^{* *} \\
(1.868)\end{array}$ \\
\hline duration*dummy & $\begin{array}{c}0.231 \\
(0.485)\end{array}$ & $\begin{array}{l}1.229^{*} \\
(0.651)\end{array}$ & $\begin{array}{l}0.0364 \\
(0.524)\end{array}$ & $\begin{array}{l}-0.247 \\
(0.875)\end{array}$ & $\begin{array}{l}0.0507 \\
(0.499)\end{array}$ \\
\hline share*dummy & $\begin{array}{c}0.0264 \\
(0.0498)\end{array}$ & $\begin{array}{c}0.0528 \\
(0.0777)\end{array}$ & $\begin{array}{c}0.0667 \\
(0.0562)\end{array}$ & $\begin{array}{c}-0.246^{* * *} \\
(0.0930)\end{array}$ & $\begin{array}{l}-0.0240 \\
(0.0533)\end{array}$ \\
\hline drawn/granted*dummy & $\begin{array}{l}-0.00469 \\
(0.0151)\end{array}$ & $\begin{array}{c}0.0463^{*} \\
(0.0254)\end{array}$ & $\begin{array}{l}-0.00545 \\
(0.0185)\end{array}$ & $\begin{array}{l}-0.0190 \\
(0.0374)\end{array}$ & $\begin{array}{c}0.0349^{* *} \\
(0.0174)\end{array}$ \\
\hline $\log (\text { credit })_{t-1} *$ dummy & $\begin{array}{l}-1.139 \\
(0.703)\end{array}$ & $\begin{array}{c}-2.472^{*} \\
(1.447)\end{array}$ & $\begin{array}{c}0.534 \\
(0.853)\end{array}$ & $\begin{array}{c}0.660 \\
(1.457)\end{array}$ & $\begin{array}{l}-1.123 \\
(0.834)\end{array}$ \\
\hline Observations & 76837 & 76837 & 76837 & 76820 & 76837 \\
\hline
\end{tabular}

Robust standard errors in parentheses - All regressions include firm and bank fixed effects. 
Table 12: Bank Heterogeneity - Interest rate changes

The table shows OLS estimates of regressions for the change in the Annual Percentage Rate, including fees and commissions, on revolving credit lines granted by the banking system to Italian non-financial firms between September 2008 and September 2009 on measures of the strength of bank-firm relationships. The sample includes a cross section of 50567 bank-firm relationships included in the Taxia database (information on interest rates from the Italian Credit Register) involving banks for which complete balance sheet information was available at June 2008 (this excludes Italian branches of foreign banks). Control variables are defined in Table 5. All regressions include firm and bank fixed effects. Column 1 includes interactions of each regressor with a dummy variable taking the value 1 if the bank's regulatory capital ratio is below $10 \%$; Column 2 includes interactions of each regressor with a dummy variable taking the value 1 if bank's interbank funding over total assets is in the top quartile of the distribution; Column 3 includes interactions of each regressor with a dummy variable taking the value 1 if the ratio of bank's flow of securitizations between 2004 and 2006 to total assets is in the top quartile of the distribution; Column 4 includes interactions of each regressor with a dummy variable taking the value 1 if bank's loan charge-offs over total loans are in the top quartile of the distribution; Column 5 includes interactions of each regressor with a dummy variable taking the value 1 if a bank is among the top 10 italian banks for total assets. Robust standard errors in parentheses. ${ }^{* * *} \mathrm{p}<0.01,{ }^{*} \mathrm{p}<0.05,{ }^{*} \mathrm{p}<0.1$.

\begin{tabular}{|c|c|c|c|c|c|}
\hline \multicolumn{6}{|c|}{ Dependent variable: $\Delta$ Gross APR } \\
\hline \multirow[b]{2}{*}{ VARIABLES } & \multirow{2}{*}{$\begin{array}{c}(1) \\
\text { Low capital }\end{array}$} & \multirow{2}{*}{$\begin{array}{c}(2) \\
\text { High Interb. }\end{array}$} & \multirow{2}{*}{$\begin{array}{c}(3) \\
\text { High Securit. }\end{array}$} & \multirow{2}{*}{$\begin{array}{c}(4) \\
\text { Hi Ch-offs } \\
\end{array}$} & \multirow{2}{*}{$\begin{array}{c}(5) \\
\text { Top10 }\end{array}$} \\
\hline & & & & & \\
\hline \multirow[t]{2}{*}{ distance } & 0.102 & -0.0862 & $0.222^{*}$ & 0.0819 & 0.171 \\
\hline & $(0.121)$ & $(0.212)$ & $(0.125)$ & $(0.290)$ & $(0.125)$ \\
\hline \multirow[t]{2}{*}{ duration } & $-0.215^{* * *}$ & $-0.247^{* * *}$ & $-0.109^{* * *}$ & 0.0321 & $-0.171^{* * *}$ \\
\hline & $(0.0307)$ & $(0.0495)$ & $(0.0325)$ & $(0.0728)$ & $(0.0291)$ \\
\hline \multirow[t]{2}{*}{ share } & $0.0108^{* * *}$ & 0.00645 & $0.00942^{* * *}$ & -0.00907 & $0.00648^{*}$ \\
\hline & $(0.00325)$ & $(0.00542)$ & $(0.00337)$ & $(0.00671)$ & $(0.00333)$ \\
\hline \multirow[t]{2}{*}{ drawn/granted } & $-0.00298 * *$ & $-0.0102^{* * *}$ & $-0.0119^{* * *}$ & -0.00425 & $-0.00613^{* * *}$ \\
\hline & $(0.00126)$ & $(0.00247)$ & $(0.00152)$ & $(0.00421)$ & $(0.00157)$ \\
\hline \multirow[t]{2}{*}{$\log (\text { credit })_{t-1}$} & $0.344^{* * *}$ & $0.601^{* * *}$ & $0.302^{* * *}$ & $0.399^{* * *}$ & $0.386^{* * *}$ \\
\hline & $(0.0550)$ & $(0.0852)$ & $(0.0559)$ & $(0.116)$ & $(0.0552)$ \\
\hline \multirow[t]{2}{*}{ distance*dummy } & 0.133 & 0.295 & -0.0602 & 0.108 & 0.0299 \\
\hline & $(0.139)$ & $(0.222)$ & $(0.147)$ & $(0.297)$ & $(0.147)$ \\
\hline \multirow[t]{2}{*}{ duration*dummy } & -0.0208 & 0.0229 & $-0.173^{* * *}$ & $-0.273^{* * *}$ & $-0.103^{* * *}$ \\
\hline & $(0.0393)$ & $(0.0533)$ & $(0.0404)$ & $(0.0756)$ & $(0.0388)$ \\
\hline \multirow[t]{2}{*}{ share*dummy } & -0.00492 & 0.00130 & -0.00123 & $0.0177^{* * *}$ & 0.00199 \\
\hline & $(0.00334)$ & $(0.00540)$ & $(0.00346)$ & $(0.00675)$ & $(0.00348)$ \\
\hline \multirow[t]{2}{*}{ drawn/granted*dummy } & $-0.00374^{* * *}$ & $0.00537^{* *}$ & $0.00840^{* * *}$ & -0.00100 & 0.00110 \\
\hline & $(0.00142)$ & $(0.00253)$ & $(0.00164)$ & $(0.00423)$ & $(0.00168)$ \\
\hline \multirow[t]{2}{*}{$\log (\text { credit })_{t-1} *$ dummy } & $0.0898^{* *}$ & $-0.214^{* * *}$ & $0.115^{* *}$ & -0.00147 & 0.0213 \\
\hline & $(0.0443)$ & $(0.0794)$ & $(0.0481)$ & $(0.113)$ & $(0.0487)$ \\
\hline Observations & 50567 & 50567 & 50567 & 50567 & 50567 \\
\hline
\end{tabular}

Robust standard errors in parentheses - All regressions include firm and bank fixed effects. 
Table 13: concentration of the local credit markets

Columns 1 and 2 of the table show OLS estimates of regressions for the rate of growth of revolving credit lines granted by the banking system to Italian non-financial firms between September 2008 and September 2009 on measures of the strength of bank-firm relationships. The sample includes a cross section of 78432 bank-firm relationships. Columns 3 and 4 show OLS estimates of regressions for the change in the Annual Percentage Rate, including fees and commissions, on revolving credit lines granted by the banking system to Italian non-financial firms between September 2008 and September 2009 on measures of the strength of bank-firm relationships. The sample includes a cross section of 50567 bank-firm relationships included in the Taxia database (information on interest rates from the Italian Credit Register). Control variables are defined in Table 5. Columns 1 and 3 include interactions of the controls for relationship lending with the Herfindahl-Hirschman Index of credit in the Local Labor Market Area the firm has its headquarter in. Columns 2 and 4 include interactions of all regressions with the Herfindahl-Hirschman Index of credit in the Local Labor Market Area the firm has its headquarter in. All regressions include firm and bank fixed effects. Robust standard errors in parentheses. *** $\mathrm{p}<0.01,{ }^{* *} \mathrm{p}<0.05,{ }^{*} \mathrm{p}<0.1$.

\begin{tabular}{|c|c|c|c|c|}
\hline & \multicolumn{2}{|c|}{$\Delta$ credit $(\%)$} & \multicolumn{2}{|c|}{$\Delta$ Gross APR } \\
\hline & (1) & $(2)$ & $(3)$ & $(4)$ \\
\hline distance & $\begin{array}{c}-4.851^{* *} \\
(2.434)\end{array}$ & $\begin{array}{l}-4.649 * \\
(2.435)\end{array}$ & $\begin{array}{r}-0.0506 \\
(0.194)\end{array}$ & $\begin{array}{r}-0.0508 \\
(0.195)\end{array}$ \\
\hline duration & $\begin{array}{l}-0.155 \\
(0.610)\end{array}$ & $\begin{array}{l}-0.153 \\
(0.613)\end{array}$ & $\begin{array}{c}-0.252^{* * *} \\
(0.0491)\end{array}$ & $\begin{array}{c}-0.251^{* * *} \\
(0.0494)\end{array}$ \\
\hline share & $\begin{array}{c}0.486^{* * *} \\
(0.0833)\end{array}$ & $\begin{array}{c}0.397^{* *} \\
(0.157)\end{array}$ & $\begin{array}{l}0.00672^{*} \\
(0.00375)\end{array}$ & $\begin{array}{c}0.0126^{* *} \\
(0.00581)\end{array}$ \\
\hline drawn/granted & $\begin{array}{c}0.0680^{* * *} \\
(0.00967)\end{array}$ & $\begin{array}{c}0.0349 \\
(0.0225)\end{array}$ & $\begin{array}{c}-0.00523^{* * *} \\
(0.000877)\end{array}$ & $\begin{array}{c}-0.00505^{* *} \\
(0.00201)\end{array}$ \\
\hline $\log (\text { credit })_{t-1}$ & $\begin{array}{c}-48.08^{* * *} \\
(1.685)\end{array}$ & $\begin{array}{c}-46.03^{* * *} \\
(3.854)\end{array}$ & $\begin{array}{c}0.398^{* * *} \\
(0.0453)\end{array}$ & $\begin{array}{c}0.275^{* *} \\
(0.110)\end{array}$ \\
\hline distance*HHI & $\begin{array}{c}12.47 \\
(13.27)\end{array}$ & $\begin{array}{c}11.15 \\
(13.29)\end{array}$ & $\begin{array}{c}1.356 \\
(1.080)\end{array}$ & $\begin{array}{c}1.360 \\
(1.085)\end{array}$ \\
\hline duration*HHI & $\begin{array}{l}6.021^{*} \\
(3.452)\end{array}$ & $\begin{array}{l}6.047^{*} \\
(3.474)\end{array}$ & $\begin{array}{c}0.187 \\
(0.286)\end{array}$ & $\begin{array}{c}0.176 \\
(0.289)\end{array}$ \\
\hline share*HHI & $\begin{array}{c}0.238 \\
(0.261)\end{array}$ & $\begin{array}{c}0.823 \\
(0.867)\end{array}$ & $\begin{array}{l}0.00621 \\
(0.0177)\end{array}$ & $\begin{array}{l}-0.0312 \\
(0.0336)\end{array}$ \\
\hline drawn/granted*HHI & & $\begin{array}{c}0.212 \\
(0.130)\end{array}$ & & $\begin{array}{l}-0.00119 \\
(0.0120)\end{array}$ \\
\hline $\log (\text { credit })_{t-1} * \mathrm{HHI}$ & & $\begin{array}{l}-13.61 \\
(21.85)\end{array}$ & & $\begin{array}{c}0.786 \\
(0.644)\end{array}$ \\
\hline Observations & 78432 & 78432 & 50809 & 50809 \\
\hline
\end{tabular}




\section{Table 14: Pre-Post-Crisis}

Column 1 shows OLS estimates of regressions for the rate of growth of revolving credit lines granted by the banking system to Italian non-financial firms between December 2005 and December 2006 (pre-crisis period) or between September 2008 and September 2009 (crisis) on measures of the strength of bank-firm relationships. The sample includes a cross section of 145760 bank-firm relationships. Column 2 shows OLS estimates of regressions for the change in the Annual Percentage Rate, including fees and commissions, on revolving credit lines granted by the banking system to Italian non-financial firms between December 2005 and December 2006 (pre-crisis period) or between September 2008 and September 2009 (crisis) on measures of the strength of bank-firm relationships. The sample includes a cross section of 97248 bank-firm relationships included in the Taxia database (information on interest rates from the Italian Credit Register). Control variables are defined in Table 5. The dummy crisis takes the value one if the relationship refers to the September 2008-September 2009 period. All regressions include firm*time and bank ${ }^{*}$ time fixed effects. ${ }^{* * *} \mathrm{p}<0.01,{ }^{* *} \mathrm{p}<0.05,{ }^{*} \mathrm{p}<0.1$.

\begin{tabular}{|c|c|c|}
\hline & $\Delta$ credit (\%) & $\Delta$ Gross APR \\
\hline & $(1)$ & $(2)$ \\
\hline distance & $\begin{array}{l}-1.956 \\
(1.361)\end{array}$ & $\begin{array}{l}-0.0827 \\
(0.0932)\end{array}$ \\
\hline duration & $\begin{array}{c}2.420 * * * \\
(0.874)\end{array}$ & $\begin{array}{c}-0.192^{* * *} \\
(0.0568)\end{array}$ \\
\hline share & $\begin{array}{c}0.477^{* * *} \\
(0.0914)\end{array}$ & $\begin{array}{l}0.00419^{*} \\
(0.00232)\end{array}$ \\
\hline drawn/granted & $\begin{array}{c}0.0896 * * * \\
(0.0131)\end{array}$ & $\begin{array}{c}-0.00379 * * * \\
(0.00101)\end{array}$ \\
\hline $\log (\text { credit })_{t-1}$ & $\begin{array}{c}-50.91^{* * *} \\
(2.287)\end{array}$ & $\begin{array}{c}0.332^{* * *} \\
(0.0449)\end{array}$ \\
\hline distance* ${ }^{*}$ crisis & $\begin{array}{l}-0.941 \\
(1.767)\end{array}$ & $\begin{array}{c}0.251^{*} \\
(0.129)\end{array}$ \\
\hline duration*crisis & $\begin{array}{c}-1.628^{*} \\
(0.915)\end{array}$ & $\begin{array}{l}-0.0310 \\
(0.0606)\end{array}$ \\
\hline share*crisis & $\begin{array}{l}0.0487 \\
(0.116)\end{array}$ & $\begin{array}{c}0.00352 \\
(0.00340)\end{array}$ \\
\hline drawn/granted* ${ }^{*}$ crisis & $\begin{array}{l}-0.0169 \\
(0.0166)\end{array}$ & $\begin{array}{l}-0.00143 \\
(0.00135)\end{array}$ \\
\hline $\log (\text { credit })_{t-1}{ }^{*}$ crisis & $\begin{array}{c}2.816 \\
(2.856)\end{array}$ & $\begin{array}{c}0.0662 \\
(0.0642)\end{array}$ \\
\hline Observations & 145760 & 97248 \\
\hline
\end{tabular}

